WSRC-TR-95-0479

\title{
Glass Composition Development for Stabilization of Lead Based Paints - (U)
}

James C. Marra

Defense Waste Processing Technology Section

Westinghouse Savannah River Company

Savannah River Technology Center Aiken, SC 29802 


\section{DISCLAIMER}

This report was prepared as an account of work sponsored by an agency of the United States Government. Neither the United States Government nor any agency thereof, nor any of their employees, makes any warranty, express or implied, or assumes any legal liability or responsibility for the accuracy, completeness, or usefulness of any information, apparatus, product, or process disclosed, or represents that its use would not infringe privately owned rights. Reference herein to any specific commercial product, process, or service by trade name, trademark, manufacturer, or otherwise does not necessarily constitute or imply its endorsement, recommendation, or favoring by the United States Government or any agency thereof. The views and opinions of authors expressed herein do not necessarily state or reflect those of the United States Government or any agency thereof. 


\section{DISCLATMER}

This report was prepared as an account of work sponsored by an agency of the United States Government. Neither the United States Government nor any agency thereof, nor any of their employees, makes any warranty, express or implied, or assumes any legal liability or responsibility for the accuracy, completeness, or usefulness of any information, apparatus, product, or process disclosed, or represents that its use would not infringe privately owned rights. Reference herein to any specific commercial product, process, or service by trade name, trademark, manufacturer, or otherwise does not necessarily constitute or imply its endorsement, recommendation, or favoring by the United States Government or any agency thereof. The views and opinions of authors expressed herein do not necessarily state or reflect those of the United States Government or any agency thereof.

This report has been reproduced directly from the best available copy.

Available to DOE and DOE contractors from the Office of Scientific and Technical Information, P.O. Box 62, Oak Ridge, TN 37831; prices available from (615) 576-8401.

Available to the public from the National Technical Information Service, U.S. Department of Commerce; 5285 Port Royal Road, Springfield, VA 22161. 


\title{
Glass Composition Development for Stabalization of Lead Based Paints(U)
}

by

\author{
J. C. Marra
}

Westinghouse Savannah River Company

Savannah River Site

Aiken, South Carolina 29808

\section{DISCLAIMER}

This report was prepared as an account of work sponsored by an agency of the United States Government. Neither the United States Government nor any agency thereof, nor any of their employees, makes any warranty, express or implied, or assumes any legal liability or responsibility for the accuracy, completeness, or usefulness of any information, apparatus, product, or process disclosed, or represents that its use would not infringe privately owned rights. Reference herein to any specific commercial product, process, or service by trade name, trademark, manufacturer, or otherwise does not necessarily constitute or imply its endorsement, recommendation, or favoring by the United States Government or any agency thereof. The views and opinions of authors expressed herein do not necessarily state or reflect those of the United States Government or any agency thereof.

\section{MASTER}

DOE Contract No. DE-AC09-89SR18035

This paper was prepared in connection with work done under the above contract number with the U. S. Department of Energy. By acceptance of this paper, the publisher and/or recipient acknowledges the U.S. Government's right to retain a nonexclusive, royalty-free license in and to any copyright covering this paper, along with the right to reproduce and to authorize others to reproduce all or part of the copyrighted paper. 


\section{DISCLAIMER}

Portions of this document may be illegible in electronic image products. Images are produced from the best available original document. 
WSRC-TR-95-0479

Rev. 0

TABLE OF CONTENTS

PAGE

Summary

1

Introduction

2

Experimental Procedures 3

$\begin{array}{ll}\text { Results and Discussion } & 4\end{array}$

Glass Formulation and Characterization - Initial Glass Formulations 4

Glass Formulation and Characterization - Second Phase Glass 6

Formulations

Chemical Composition Analysis of Select Glasses 7

Scanning Electron Microscopy of Select Glasses 7

Recommendations from Glass Formulation Studies $\quad 8$

Incorporation of Lead in the Glass Structure 9

$\begin{array}{ll}\text { Conclusions } & 10\end{array}$

$\begin{array}{ll}\text { Acknowledgments } & \cdot 10\end{array}$

References $\quad 11$ 
WSRC-TR-95-0479

Rev. 0

THIS PAGE INTENTIONALLY LEFT BLANK 
WSRC-TR-95-0479

Rev. 0

APPROVALS

Soured C. Mlime

Jagues C. Marra, Author

Defense Waste Processing Technology Section

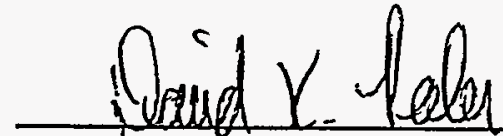

David K. Peeler, Technical Reviewer

Defense Waste Processing Technology Section
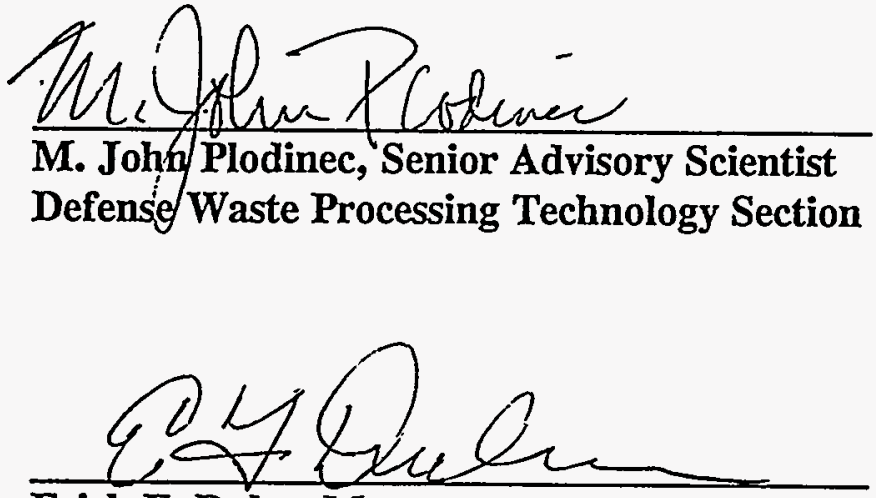

Erich F. Duhn, Manager

Defense Waste Processing Technology Section
Date: $12 / 11 / 95$

Date: $12 / 11 / 95$

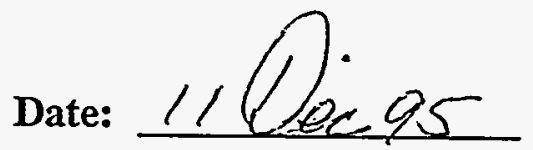


WSRC-TR-95-0479

Rev. 0

THIS PAGE INTENTIONALLY LEFT BLANK 
WSRC-TR-95-0479

Revision 0

Keywords: Vitrification, U.S. Army Corps of Engineers Construction Engineering Research Laboratory (CERL), flame spray process, lead based organic coatings, hazardous waste, lead abatement

Glass Composition Development for Stabilization of Lead Based Paints - (U)

\section{Summary}

The U. S. Army Corps of Engineers Construction Engineering Research Laboratory (CERL) is developing technologies to remove and stabilize lead containing organic coatings. A project was funded by CERL to develop appropriate glass compositions for use in their stabilization process. The acceptability of prospective compositions was primarily based on the leachability of the hazardous constituents of the glasses as determined by the Toxic Characteristic Leaching Procedure (TCLP). Attempts were also made, however, to develop glasses with physical characteristics and prosessing properties similar to previous successful formulations. Four families of glasses were examined including: alkali borosilicate (BS), sodium barium silicate (SBS), lead iron phosphate (PFP), and "commercial" lead silicate. Glass compositions to stabilize organic coatings with four hazardous constituent combinations were desired from this effort. The waste permutations included (as oxides): lead only; copper only; lead and copper; and lead, cadmium and chromium. The borosilicate glasses were the most successful in stabilizing the hazardous constituents. The most successful glass frit composition for stabilizing all waste permutations was: $5.1 \mathrm{wt} \% \mathrm{Al}_{2} \mathrm{O}_{3}, 10.0 \mathrm{wt} \%$ $\mathrm{B}_{2} \mathrm{O}_{3}, 12.3$ wt $\% \mathrm{Fe}_{2} \mathrm{O}_{3}, 2.0$ wt $\% \mathrm{Li}_{2} \mathrm{O}, 16.5$ wt $\% \mathrm{Na}_{2} \mathrm{O}$ and 54.1 wt $\% \mathrm{SiO}_{2}$. 


\section{Introduction}

Exposure to lead can lead to adverse health affects including permanent damage to the central nervous system. Common means of exposure to lead are from ingestion of lead paint chips or breathing of dust from deteriorating painted surfaces. The U. S. Army has over 101 million square feet of buildings dating to World War II or earlier [1]. Many of these structures were built before the 1978 ban on lead based paints. The U. S. Army Corps of Engineers CERL is developing technologies to remove and stabilize lead containing organic coatings. Promising results have been achieved using a patented flame spray process that utilizes a glass frit to stabilize the hazardous constituents [1]. When the glass frit is sprayed onto the paint containing substrate, differences in thermal expansion coefficients between the frit and the paint results in spalling of the paint from the substrate surface. The removed fragments are then collected and remelted to stabilize the hazardous constituents and allow for disposal as non-hazardous waste. Similar successful results using a patented process involving microwave technology for paint removal have also been achieved. In this process, the painted surface is coated with a microwave coupling compound that when exposed to microwave energy results in the spalling of the hazardous paint from the surface. The fragments can again be accumulated and remelted for stabilization and disposal.

An effort has been completed by Westinghouse Savannah River Company (WSRC) Savannah River Technology Center (SRTC) to develop appropriate glass formulations to stabilize lead and other RCRA hazardous metals contained in lead-based paints. Four separate tasks were identified in a Scope of Work to complete the program [2].

Glass formulation development comprised Task 1. Previous glass formulations were utilized as a basis for new composition development efforts. New formulations were designed to have physical properties (such as melt temperature and viscosity) comparable to previous successful glass compositions. Typical glass formulation additives, used to stabilize waste streams across the Department of Energy (DOE) complex, were examined. The development of simple, cost-effective glasses was an integral part of this effort. The glasses were evaluated based on leachability (Task 2), homogeneity, and viscosity.

The chemical stability of candidate glasses was assessed in Task 2. This was performed by subjecting glasses to the modified EPA Toxic Characteristic Leaching Procedure (TCLP) ${ }^{*}$. Elemental releases of RCRA hazardous metals were compared to EPA release limits for land disposal.

* The modified TCLP does not require $100 \mathrm{~g}$ of material for analysis, however, the ratio of leachate volume to weight of leached material is preserved. 
Mechanistic examination for the immobilization of lead in glass was prescribed in Task 3. References detailing glass structure were consulted for this assessment. The experimental results and the mechanistic analysis results are presented in this final report (Task 4).

\section{Experimental Procedure}

Composition Development and Preparation

Previous development efforts at the U. S. Army Corps of Engineers CERL determined that SRL Frit 165 Technical Data Summary (TDS) served as a suitable frit composition for stabilization of lead-based paints (Table I) [3]. This composition, in actuality, was developed as a surrogate waste glass formulation for glass durability assessment in varying disposal environments [4]. Thus, the composition contained several components which were present as constituents of radioactive waste and did not play an important role in glass processing or in the structure of the final glass. Initial formulation attempts were, therefore, aimed at identifying the nonessential elements and removing them from the compositions. Additionally, since Frit 165 TDS achieved reasonably good success in stabilizing the RCRA hazardous metals and was readily processable by CERL, development of glasses with similar physical characteristics appeared logical. A glass viscosity model was used to estimate the viscosity of Frit 165 TDS at various temperatures [5]. These values served as a benchmark for the development of new candidate compositions.

Four glass families were examined in the glass formulation development effort. Alkali borosilicates (BS), such as Frit 165 TDS, are used extensively for waste glass compositions because of their high durability and good processability. Sodium barium silica (SBS) glasses were developed previously for stabilization of heavy metal constituents at the Fernald Site [6]. Lead iron phosphate (PFP) glasses are relatively low temperature compositions with reasonable durability. Commercial lead silicate glasses are used for stemware and decorative pieces because of an inherent high luster and in electronic applications because of a high degree of workability.

To assess the suitability of the glass compositions to the varying hazardous wastes which may be encountered in field use of the flame spray process, four hazardous component "permutations" were examined. The permutations included: $\mathrm{PbO}$ only; $\mathrm{CuO}$ only; 50 wt \% PbO/50 wt \% CuO; and 80 wt \% PbO/10 wt \% CdO/10 wt \% $\mathrm{Cr}_{2} \mathrm{O}_{3}$. The waste loading in the glass of each of the permutations was $25 \mathrm{wt} \%$ on a dry oxide basis.

All glasses were formulated using reagent grade chemicals. Aluminum, silicon, iron, lead and chromium were added as their oxides. Sodium and lithium were 
introduced as carbonates while boron was added as boric acid. Copper and cadmium were added to the batches as hydrated nitrates. Glasses were melted for 4 hours in covered alumina crucibles and allowed to air cool in the crucibles. The alkali borosilicate, sodium barium silicate and commercial lead silicate glasses were melted at $1100^{\circ} \mathrm{C}$. The lead iron phosphate compositions were initially melted at $900^{\circ} \mathrm{C}$. This first attempt was unsuccessful so a second melt at $750^{\circ} \mathrm{C}$ was performed.

\section{Analysis of Glasses}

The leachability of hazardous constituents from the glasses was assessed using the modified TCLP which does not require $100 \mathrm{~g}$ of material for analysis. The ratio of leachate volume to weight of leached material in this test is consistent with the standard TCLP, however.

The homogeneity of the glass was assessed by visual observation, microscopic examination and crystallinity determination. Initially, all glasses were examined visually to determine uniformity and identify the presence of macroscopic inhomogeneities and second phases. The glasses, ground to -200 mesh, were then analyzed by X-ray diffraction (XRD) for detection and identification of any crystalline species. The XRD instrument employed had a detection limit of approximately 1 volume percent. Selected samples were analyzed by scanning electron microscopy (SEM) coupled with energy dispersive spectroscopy (EDS) to examine the homogeneity of the glasses on a microscale.

\section{Results and Discussion}

Glass Formulation and Characterization-Initial Glass Formulations Initially, five frit compositions were tested (Table II). The initial frit compositions included: two alkali borosilicate (BS-1 and BS-2), one sodium barium silicate (SBS-1), one lead iron phosphate (PFP-1), and Frit 165 TDS. When combined with the various waste permutations, this resulted in analysis of 16 glasses.

The initial frit formulations were developed based on previous successful glass formulation efforts. The BS-1 composition was formulated based on the Frit 165 TDS glass. In this composition, the elements considered nonessential (namely $\mathrm{Ca}, \mathrm{Mn}, \mathrm{Mg}$ and $\mathrm{Zr}$ ) were removed from the Frit 165 TDS formulation and the resulting glass was scaled to $100 \%$ based on glass formulation principles and knowledge. Achieving a predicted viscosity comparable to the Frit 165 TDS composition was paramount in this exercise (Table II). The BS-2 composition was identical to the BS-1 composition 
except for the alkali constituents in the glasses. Since lithium is typically an expensive additive, all alkali was added to the BS-2 glass as sodium. Again, reasonable agreement in estimated viscosities was desirable (Table II). The SBS-1 glass was based on previous glass formulation efforts for the stabilization of heavy metals [6]. This formulation is essentially an analog of a soda lime silica glass. The estimated viscosities at temperature for this glass system were again consistent with Frit 165 TDS (Table II). The PFP-1 glass composition was extrapolated from a "pseudo-ternary" diagram determined in a previous research effort [7]. Since the viscosity predication model was developed for silicate glasses, no viscosities could be estimated for the lead iron phosphate glass.

From visual examination of these initial glasses, the BS formulations appeared to produce the most homogeneous glass products (Figures 1 to 5). All the alkali borosilicate glasses except for the "copper only" waste permutation appeared to produce primarily homogeneous glasses. Some macroscale inhomogeneity occurred in the SBS-1 glasses as evidenced by a greenish-yellow surface layer (likely chromate salt) forming in the SBS-1: $80 \mathrm{~Pb} / 10 \mathrm{Cd} / 10 \mathrm{Cr}$ formulation and a bluish surface layer (likely a copper compound) at the crucible wall in the SBS-1: $50 \mathrm{~Pb} / 50 \mathrm{Cu}$ glass. The PFP-1 compositions did not form glasses (Figure 4). The Frit 165 TDS: Pb only glass formed a homogeneous product. The Frit 165 TDS: $80 \mathrm{~Pb} / 10 \mathrm{Cd} / 10 \mathrm{Cr}$ had a nonuniform, "bubbly" layer on the surface of the solidified melt and at the crucible wall. A summary of the visual observations for the initial formulations is listed in Table III.

$X$-ray diffraction (XRD) scans were performed on the glasses in an attempt to identify crystalline species. The results of the x-ray diffraction scans are included in Table III. Most of the glasses were found to be amorphous. The "copper only" compositions showed that a significant amount of copper oxide (cuprite) was present. From this result it is obvious that $25 \mathrm{wt} \%$ copper oxide is not readily soluble in these glasses. Iron phosphate peaks dominated the XRD scans for the lead iron phosphate formulations. The Frit 165 TDS glass compositions were generally amorphous. However, in the Frit 165 TDS: $80 \mathrm{~Pb} / 10 \mathrm{Cd} / 10 \mathrm{Cr}$ formulation, crystalline species with a spinel structure (similar to nickel iron oxide - trevorite) were detected. This observation was not surprising since isomorphous substitution of chromium for iron, resulting in the formation of iron chromium spinels, is frequently observed in waste glasses [9].

The modified TCLP results for these initial glass formulations indicated that the BS glasses were the most promising for the stabilization of the hazardous constituents (Table IV). The Frit 165 TDS glasses (Frit 165 TDS: Pb only and Frit 165 TDS 80 $\mathrm{Pb} / 10 \mathrm{Cd} / 10 \mathrm{Cr}$ ) both passed all TCLP release limit requirements. The release values for the Frit 165 TDS: Pb only glass in this study ( $3.417 \mathrm{ppm}$ ) was comparable to 
previous results obtained by CERL for a Frit 165 TDS - $25 \%$ PbO glass (4.28 ppm) [2]. However, a few of the initial BS glasses did not meet TCLP requirements for the release of lead and cadmium. The BS-1: $\mathrm{Pb}$ only formulation failed for release of lead while the BS-1: $80 \mathrm{~Pb} / 10 \mathrm{Cd} / 10 \mathrm{Cr}$ composition failed for release of lead and cadmium. The BS-1 glasses had a high alkali content (especially on a molar basis) which may account for the poor performance. High alkali content in waste glasses has been observed to decrease durability [9].

The hazardous element releases in the SBS-1 glasses were almost an order of magnitude higher than in the comparable BS glasses (Table IV). The releases in the PFP-1 compositions were extremely high and were indicative of a poor final product (Table IV).

Glass Formulation and Characterization - Second Phase Glass Formulations In an attempt to improve on the glasses from the initial formulation effort, two new frit compositions were developed and analyzed in a second test phase. A third alkali borosilicate frit (BS-3) was developed based on the BS-1, BS-2 and Frit 165 TDS compositions (Table $\mathrm{V}$ ). In formulating the BS-3 frit, the total alkali was slightly reduced and the alumina content was slightly increased from the BS-1 and BS-2 compositions (alumina additions have been shown to increase the durability of waste glasses [9]). The ratio of lithium to sodium (on a wt $\%$ basis) was also decreased from the BS-1 formulation lowering the alkali content on a molar basis. In comparison to Frit 165 TDS, the nonessential elements were again removed and the sodium and lithium contents were set so the BS-3 frit was comparable to Frit 165 TDS on a molar alkali oxide basis. The $\mathrm{Pb}$ only, $80 \mathrm{~Pb} / 10 \mathrm{Cd} / 10 \mathrm{Cr}$, and $50 \mathrm{~Pb} / 50 \mathrm{Cu}$ waste permutations were examined with the BS-3 frit. A comparable "commercial" lead silicate glass, obtained from a literature reference, was also tested in the second phase [10]. The PbO content in this glass as listed was $28 \mathrm{wt} \%$, so the glass was renormalized with respect to the other constituents to produce a formulation with a 25 wt \% PbO content (Table V). For the "commercial" lead silicate glass composition only the $\mathrm{Pb}$ only waste permutation was tested. In this second phase of testing, the PFP-1: $\mathrm{Pb}$ only composition was remelted at $750^{\circ} \mathrm{C}$ to see if lead volatilization was the cause of the unsatisfactory results in the initial tests. The BS-3 and "commercial" lead silicate glass were melted at $1100^{\circ} \mathrm{C}$.

The estimated viscosities for the second phase glasses are also found in Table $\mathrm{V}$ while visual observations are summarized in Table VI. The alkali borosilicate BS-3 frit formulation produced good homogeneous glasses (Figure 6). The "commercial" lead silicate formulation produced a clear glass that was filled with gas bubbles (Figure 7). An extremely high viscosity (predicted to be in excess of 1000 poise) undoubtedly 
hindered the dissipation of gas bubbles from the melt (Table $V$ ). The lead iron phosphate composition again yielded unsatisfactory results (Figure 4). $\mathrm{X}$-ray diffraction results indicated that the BS-3 formulations and commercial lead silicate formulation produced amorphous glass products (Table VI). The scan for the iron lead phosphate composition was again dominated by iron phosphate peaks (Table VI).

The BS-3 and the "commercial" lead silicate glasses all had acceptable TCLP releases (Table VIn). The hazardous element releases for the BS-3 glasses were typically a little lower than releases for the Frit 165 TDS glasses. The release of lead from the "commercial" lead silicate glass was approximately 2 times lower than the lead release from the Frit 165 TDS: Pb only glass (Table VII). The release of lead from the lead iron phosphate glass was again extremely high (Table VII).

\section{Chemical Composition Analysis of Select Glasses}

The chemical composition of a number of glass formulations were analyzed by chemically digesting the glass and analyzing the resulting solution by inductively coupled plasma (ICP) spectroscopy. This analysis was performed as a check to ensure the glasses were properly prepared and to ascertain the degree of incorporation of the hazardous components into the glass. In all cases the analyzed chemical compositions were close to the target compositions (Table VIII). This implies that the hazardous components were readily incorporated into the glasses.

\section{Scanning Electron Microscopy of Select Glasses}

Scanning electron microscopy (SEM) coupled with energy dispersive spectroscopy (EDS) was used to identify any heterogeneities in the glass compositions. Particular emphasis was placed on identification and corroboration of crystalline species identified in the $x$-ray diffraction analyses. Additionally, SEM/EDS was used to examine for microscale inhomogeneities, detection of insoluble chemical species and chemical identification of surface layers on the glasses. Due to the relative success of the borosilicate formulations in comparison to the other glasses, only the BS series of glasses were examined by SEM/EDS.

Three $\mathrm{Pb}$ only glass compositions were examined: Frit $165 \mathrm{TDS}-\mathrm{Pb}$ only; $\mathrm{BS}-2 \mathrm{~Pb}$ only; and $\mathrm{BS}-3 \mathrm{~Pb}$ only. Examination of these three formulations indicated that homogeneous, crystal-free glasses resulted (Figures 8-10).

Three of the $80 \mathrm{~Pb} / 10 \mathrm{Cd} / 10 \mathrm{Cr}$ permutation glasses were examined: Frit 165 TDS-80 $\mathrm{Pb} / 10 \mathrm{Cd} / 10 \mathrm{Cr}$; BS-1 $80 \mathrm{~Pb} / 10 \mathrm{Cd} / 10 \mathrm{Cr}$; and BS-3 $80 \mathrm{~Pb} / 10 \mathrm{Cd} / 10 \mathrm{Cr}$. These glasses were generally homogeneous, however, a minor fraction of chromium rich 
crystalline species were observed in the glasses (Figures 11-13). The oxide crystals observed were primarily comprised of chromium with a minor amount of iron. These crystals are likely spinels with the chemical form $\mathrm{AB}_{2} \mathrm{O}_{4}$ where the chromium and iron cations can occupy either of the A or B lattice sites [11]. Spinel crystals were detected in the XRD scans performed on a Frit $165 \mathrm{TDS} 80 \mathrm{~Pb} / 10 \mathrm{Cd} / 10 \mathrm{Cr}$ sample. Chromium/iron spinel crystals have been previously observed in high level nuclear waste glasses and were determined to not affect durability [8].

Two of the $50 \mathrm{~Pb} / 50 \mathrm{Cu}$ series of glasses were analyzed: $\mathrm{BS}-250 \mathrm{~Pb} / 50 \mathrm{Cu}$; and $\mathrm{BS}-3$ $50 \mathrm{~Pb} / 50 \mathrm{Cu}$ with varying results. The BS-2 sample visually appeared homogeneous with no evidence of crystalline species (Figure 14). The BS-3 sample had one small area that appeared "frosty" or "not glassy". In this area copper rich and iron-copper rich oxide crystals were found (Figure 15). These crystals comprised less than 1 vol \% of the sample since they were undetected by $x$-ray diffraction. The "star-shaped" crystals are undoubtedly copper oxide (see discussion below) while the iron-copper rich crystals may be of the spinel form. It is difficult to determine if these crystals were only present in the BS-3 glass or were also present (though undetected by analysis) in the other $50 \mathrm{~Pb} / 50 \mathrm{Cu}$ glasses. It is likely that the latter is true since a copper of content of $12.5 \mathrm{wt} \%$ is typically very high for waste glass formulations and likely exceeds the solubility of copper in these borosilicate systems.

One glass of the $\mathrm{Cu}$ only series was examined by SEM/EDS: BS- $1 \mathrm{Cu}$ only. The XRD results indicated a large volume of copper oxide (cuprite) was present in all the Cu only glass compositions. A large volume of "star shaped" crystals were observed in the BS1 glass (Figure 16). The crystals were found to be comprised of copper and oxygen and were thus identified as the cuprite crystals. Additionally, in one of the examined areas, an area rich in iron and copper was observed (Figure 16). The oxygen sensitivity in EDS is somewhat limited so it is difficult to ascertain if these are ironcopper oxide crystals (i.e. spinels) or a "vein" of reduced metal in the glass. The latter is somewhat unlikely since there were no common reducing agents (e.g. carbon) in these formulations and the glasses were melted in air in covered but unsealed crucibles. The significant amount of copper containing crystals present clearly indicates these formulations exceeded the solubility of copper in the glass.

\section{Recommendations from Glass Formulation Studies}

The results of the glass formulation effort indicate that the borosilicate glasses are superior for incorporation of the hazardous species (lead, chromium and cadmium) into the glass matrix. As was observed in previous studies, Frit 165 TDS is an acceptable formulation for the stabilization of these hazardous species. The results of this effort show that all of the "unnecessary" constituents of Frit 165 TDS can be removed from 
the frit composition. These include: calcium, magnesium, manganese, and zirconium. The BS-3 frit formulation was found to have the most universal success in stabilization of all the hazardous species and is, thus, the recommended frit formulation from this study. In the BS-3 frit, the alkali constituents were added as sodium and lithium with the lithium content significantly reduced from the Frit 165 TDS composition. This will result in a cost savings in the manufacture of the frit since lithium costs approximately 30 times more to add to a glass than sodium. If it is necessary to further reduce the cost of the frit, studies should continue based on this composition to determine optimal alkali addition levels. In the BS-2 frit formulation, all of the lithium was replaced by sodium. The resulting frit readily stabilized lead at a $25 \mathrm{wt} \%$ loading. However, the overall performance of BS-2 was inferior to the BS-3 composition.

The "commercial" frit formulation was also promising for the stabilization of lead. This composition was observed to be highly viscous at the $1100^{\circ} \mathrm{C}$ melt temperature employed. This lead glass formulation would likely require significantly higher melting temperatures to facilitate processing. Fabrication of the frit would also require high temperatures which might increase frit cost. Additional analysis of this composition should be performed, however, due its simplicity and the relatively low cost of the additives.

Sodium barium silicate and lead iron phosphate glasses are not recommended for use in the flame spray process. Although the sodium barium silicate compositions formed glassy products, the leachabilities were excessive. The lead iron phosphate glasses tested in this study were based on previous work involving this glass forming system [7]. These formulations did not form glasses indicating that this glass system is very compositionally sensitive.

\section{Incorporation of Lead in the Glass Structure}

Lead can be readily incorporated into silicate glasses. It has been shown that lead can act as a network modifier and/or a network former in glass structures [12]. PbO can be present up to as much as $92 \mathrm{wt} \%$ in lead silicate glasses and possibly up to $94 \mathrm{wt} \%$ in borate compositions [12].

Several studies have examined the manner in which lead is incorporated into the glass structure. Based upon XRD analyses of lead silicate glasses (up to $86.4 \mathrm{wt} \%$ ), Bair suggested that for glasses with composition $2 \mathrm{PbO} \cdot \mathrm{SiO}_{2}$ all the $\mathrm{SiO}_{4}$ tetrahedra are connected to one another via a lead atom [13]. The lead, therefore, takes a network forming role where each oxygen atom is connected to one lead atom and one silicon atom. From later XRD work, the coordination of lead in the glass structure was hypothesized and possible structures of $2 \mathrm{PbO}^{-S_{i O}}$ were developed (Figure 17) [14]. It 
was thought that, if the lead was in 2-coordination, an open structure would result which could accommodate additional $\mathrm{PbO}$ in the glass structure (Figure 17.a). A more likely structure (supported by nuclear magnetic resonance (NMR) analyses) is represented in Figure 17.b. [14]. In this scenario lead is contained in $\mathrm{PbO}_{4}$ pyramids where lead forms the vertex. The $\mathrm{PbO}_{4}$ pyramids are arranged in a "twisted" manner with varying $\mathrm{Pb}-\mathrm{O}$ interatomic distances. The differences in the interatomic distances contribute to the randomness of the glass structure.

\section{Conclusions}

A study was completed to develop glass formulations to stabilize hazardous wastes resulting from the removal of organic coatings from buildings and structures. Emphasis in the study was place on the stabilization of lead (up to $25 \mathrm{wt} \%$ ) in the glass. The following conclusions were drawn from this effort:

- Borosilicate glass compositions were the most successful in stabilizing the hazardous waste constituents.

- For the four waste permutations, the most universally successful frit composition was the BS-3 formulation consisting of: $54.1 \mathrm{wt} \% \mathrm{SiO}_{2} ; 16.5 \mathrm{wt}$ $\% \mathrm{Na}_{2} \mathrm{O} ; 12.3$ wt $\% \mathrm{Fe}_{2} \mathrm{O}_{3} ; 10.0$ wt $\% \mathrm{~B}_{2} \mathrm{O}_{3} ; 5.1$ wt $\% \mathrm{Al}_{2} \mathrm{O}_{3}$; and 2.0 wt \% $\mathrm{Li}_{2} \mathrm{O}$.

- A "commercial" lead silicate glass composition was found to effectively stabilize lead in the glass. However, due to potential difficulties in processing this composition additional analysis of this glass is necessary.

- A review of the literature showed that lead is readily incorporated into glass structures. The lead ions can take a network former or modifier role in the glass.

\section{Acknowledgments}

This work was funded by the U.S. Army Corps of Engineers - Construction Engineering Research Laboratory (CERL) in Champaign, IL. This effort was completed under the direction of Dr. A. Kumar, Mr. L. Lattimore, and Dr. J. Boy of CERL. Their assistance was greatly appreciated. 
Dr. C. M. Jantzen is acknowledged for assisting in the definition of initial glass formulations for testing and for other helpful discussions during this effort. The efforts of Ms. P. A. Toole in the batching and melting of the glasses is gratefully acknowledged. The following individuals of the SRTC Analytical Development Section performed analyses to support this effort: TCLP testing under the direction of Dr. M. J. Whitaker, XRD performed by Dr. A. R. Jurgensen, SEM performed by Mr. J. R. Durden, chemical digestions performed by Ms. B. H. Burch, and ICP analysis performed by Ms. M. K. Cooley.

\section{References}

1. "Fact Sheet", U. S. Army Corps of Engineers Construction Engineering Research Laboratory, P. O. Box 9005, Champaign, IL, October, 1994.

2. J. C. Marra, "Cost Estimate for Glass Composition Development for the Immobilization of Lead Based Paint", SRT-GTC-95-0024, Westinghouse Savannah River Company, Aiken, SC, April, 13, 1995.

3. S. W. Covey, "Investigation and Field Analysis of Lead-based Paint Removal Systems", M. S. Thesis, University of Illinois at Urbana-Champaign, 1995.

4. W. G. Ramsey and G. G. Wicks, "WIPP/SRL In-situ Tests; Laboratory Support Experiments", Nuclear Waste Management III, Ceramic Transactions, Vol. 9, American Ceramic Society, Westerville, OH, pp. 37-51, 1990.

5. C. M. Jantzen, "First Principles Process-Product Models for Vitrification of Nuclear Waste: Relationship of Glass Composition to Glass Viscosity, Resistivity, Liquidus Temperature, and Durability", Nuclear Waste Management IV, Ceramic Transactions, Vol. 23, American Ceramic Society, Westerville, $\mathrm{OH}$, pp. 37-51, 1992.

6. D. S. Janke, C. C. Chapman and R. A. Vogel, "Results of Vitrifying Fernald K65 Residue", Nuclear Waste Management IV, Ceramic Transactions, Vol. 23, American Ceramic Society, Westerville, OH, pp. 53-61, 1992.

7. C. M. Jantzen, "Investigation of Lead-Iron-Phosphate Glass for SRP Waste", Nuclear Waste Management II, Advances in Ceramics, Vol. 20, American Ceramic Society, Westerville, OH, pp. 157-165, 1986. 
8. C. M. Jantzen and D. F. Bickford, "Leaching of Devitrified Glass Containing Simulated SRP Nuclear Waste", Materials Research Society Symposium Proceedings, Vol. 44, pp. 136-146, 1985.

9. P. R. Hrma and G. F. Piepel, "Property/Composition Relationships for Hanford High-Level Waste Glasses Melting at $1150^{\circ}$ C", Volumes 1 and 2, PNL-10359, Pacific Northwest Laboratory, Richland, WA, 1994.

10. F. E. Woolley, Glass Tutorial Lecture Notes, Westinghouse Hanford Company, Richland, WA, 1994.

11. W. D. Kingery, H. K. Bowen and D. R. Uhlmann, Introduction to Ceramics, John Wiley and Sons, New York, pp. 61-70, 1976.

12. A. K. Varshneya, Fundamentals of Inorganic Glasses, Academic Press, Inc. Boston, pp. 115-116, 1994.

13. G. J. Bair, "The Constitution of Lead Oxide-Silica Glasses: I Atomic Arrangement", Journal of the American Ceramic Society, 19, pp. 335-338, 1936.

14. M. F. Mydlar, N. J. Kreidl, J. K. Hendren and G. T. Clayton, "X-ray Diffraction Study of Lead Silicate Glasses", Physical Chemistry of Glass, 11, pp. 198-204, 1970. 
James C. Marra

October 19, 1995
WSRC-TR-95-0479, Rev. 0

Page 13 of 37

Table I. Frit 165 TDS Composition

\section{Component}

$\mathrm{SiO}_{2}$

$\mathrm{Fe}_{2} \mathrm{O}_{3}$

$\mathrm{Na}_{2} \mathrm{O}$

$\mathrm{B}_{2} \mathrm{O}_{3}$

$\mathrm{Li}_{2} \mathrm{O}$

$\mathrm{Al}_{2} \mathrm{O}_{3}$

$\mathrm{MnO}_{2}$

$\mathrm{CaO}$

$\mathrm{ZrO}_{2}$

$\mathrm{NiO}$

$\mathrm{MgO}$

$\mathrm{PbO}$

$\mathrm{F}$

$\mathrm{Cl}$

TOTAL
Concentration (wt \%)

54.1

12.3

10.3

6.8

4.7

4.1

2.9

1.5

1.2

0.9

0.8

0.05

0.06

0.05

99.76 
James C. Marra

October 19, 1995
WSRC-TR-95-0479, Rev. 0 Page 14 of 37

Table I. Initial Frit Compositions and Predicted Viscosities

\begin{tabular}{|c|c|c|c|c|c|}
\hline Component & BS-1 & BS-2 & SBS-1 & PFP-1 & Frit 165 TDS \\
\hline $\mathrm{SiO}_{2}$ & 54.1 & 54.1 & 64.71 & - & 54.1 \\
\hline $\mathrm{Na}_{2} \mathrm{O}$ & 15.0 & 19.5 & 13.18 & - & 10.3 \\
\hline $\mathrm{Fe}_{2} \mathrm{O}_{3}$ & 12.3 & 12.3 & - & 11.1 & 12.3 \\
\hline $\mathrm{B}_{2} \mathrm{O}_{3}$ & 10.0 & 10.0 & - & - & 6.8 \\
\hline $\mathrm{Li}_{2} \mathrm{O}$ & 4.5 & - & 10.29 & - & 4.7 \\
\hline $\mathrm{Al}_{2} \mathrm{O}_{3}$ & 4.1 & 4.1 & 3.80 & - & 4.1 \\
\hline $\mathrm{BaO}$ & - & - & 6.48 & - & - \\
\hline $\mathrm{CaO}$ & - & - & 1.54 & - & 1.5 \\
\hline $\mathrm{P}_{2} \mathrm{O}_{5}$ & - & - & - & 88.9 & - \\
\hline $\mathrm{MnO}_{2}$ & - & - & - & - & 2.9 \\
\hline $\mathrm{ZrO}_{2}$ & - & - & - & - & 1.2 \\
\hline $\mathrm{NiO}$ & - & - & - & - & 0.9 \\
\hline $\mathrm{MgO}$ & - & - & - & - & 0.8 \\
\hline Viscosity (Poise) ${ }^{*}$ & 56.0 & 103.2 & 59.8 & $\mathrm{n} / \mathrm{a}^{* *}$ & 80.0 \\
\hline
\end{tabular}

* Predicted viscosity for glasses at $1100^{\circ} \mathrm{C}$ using viscosity algorithm [5]

** Algorithm is not applicable to phosphate glasses 
Table III. Visual Observations and XRD Results of Initial Glasses

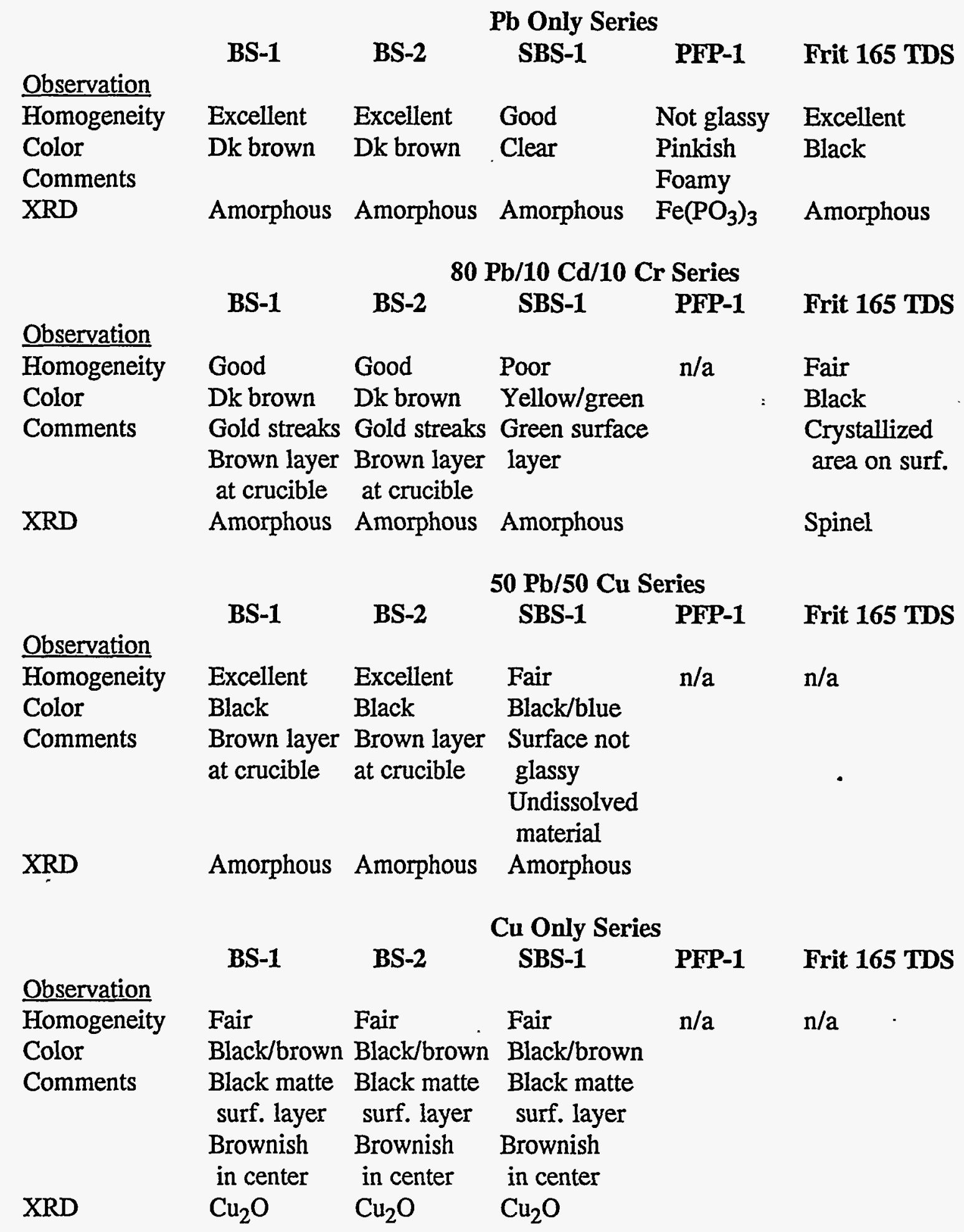


James C. Marra

October 19, 1995
WSRC-TR-95-0479, Rev. 0

Page 16 of 37

Table IV. TCLP Results for Initial Glasses

$\underline{\text { RCRA Element }}$

BS-1

(TCLP Limit)

$\mathrm{Pb}$ (5 ppm)

7.206

$0.8927 \quad .52 .15$

2925

3.417

$80 \mathrm{~Pb} / 10 \mathrm{Cd} / 10 \mathrm{Cr}$ Series (releases in ppm)

$\begin{array}{llll}\text { BS-1 } & \text { BS-2 } & \text { SBS-1 } & \text { PFP-1 }\end{array}$

$\underline{\text { RCRA Element }}$

(TCLP Limit)

\begin{tabular}{|c|c|c|c|c|c|}
\hline $\mathrm{Pb}(5 \mathrm{ppm})$ & 7.736 & 4.982 & 28.87 & 2764 & 3.152 \\
\hline $\mathrm{Cd}(1 \mathrm{ppm})$ & 1.430 & 1.225 & 6.791 & 330.3 & 0. \\
\hline $\mathrm{Cr}(5 \mathrm{ppm})$ & 0.085 & 0.068 & 0.120 & 0.288 & 0.02 \\
\hline
\end{tabular}

Cr (5 ppm)

BS-1

$\mathrm{Pb} / 50 \mathrm{Cu}$ Series (releases in ppm)

BS-2 $\quad$ SBS-1 $\quad$ PFP-1 Frit 165 TDS

RCRA Element

(TCLP Limit)

$\begin{array}{llllll}\mathrm{Pb}(5 \mathrm{ppm}) & 1.375 & 4.724 & 31.73 & \mathrm{n} / \mathrm{a} & \mathrm{n} / \mathrm{a} \\ \mathrm{Cu}^{*} & 1.720 & 5.322 & 38.79 & & \end{array}$

\begin{tabular}{|c|c|c|c|c|c|}
\hline \multirow[b]{3}{*}{ RCRA Element } & & \multicolumn{3}{|c|}{$\mathrm{Cu}$ Only Series (releases in ppm) } & \multirow{2}{*}{ Frit $165 \mathrm{TDS}$} \\
\hline & BS-1 & BS-2 & SBS-1 & PFP-1 & \\
\hline & & & & & \\
\hline $\mathrm{Cu}^{*}$ & 27.53 & 11.47 & 40.93 & $\mathrm{n} / \mathrm{a}$ & $\mathrm{n} / \mathrm{a}$ \\
\hline
\end{tabular}


Table V. Second Phase Frit Compositions and Predicted Viscosities

\begin{tabular}{|c|c|c|c|}
\hline Component & BS-3 & Pb Comm. & PFP-1 (750 C) \\
\hline $\mathrm{SiO}_{2}$ & 54.1 & 79.1 & - \\
\hline $\mathrm{Na}_{2} \mathrm{O}$ & 16.5 & 5.6 & - \\
\hline $\mathrm{Fe}_{2} \mathrm{O}_{3}$ & 12.3 & - & 11.1 \\
\hline $\mathrm{B}_{2} \mathrm{O}_{3}$ & 10.0 & - & - \\
\hline $\mathrm{Li}_{2} \mathrm{O}$ & 2.0 & - & - \\
\hline $\mathrm{Al}_{2} \mathrm{O}_{3}$ & 5.1 & 3.5 & - \\
\hline $\mathrm{K}_{2} \mathrm{O}$ & - & 11.8 & - \\
\hline $\mathrm{P}_{2} \mathrm{O}_{5}$ & - & 88.9 & \\
\hline Viscosity (Poise) ${ }^{*}$ & 96.4 & 1080 & $\mathrm{n} / \mathrm{a}^{* *}$ \\
\hline
\end{tabular}

* Predicted viscosity for glasses at $1100^{\circ} \mathrm{C}$ using viscosity algorithm [5] ** Algorithm is not applicable to phosphate glasses 
James C. Marra

October 19, 1995
WSRC-TR-95-0479, Rev. 0

Page 18 of 37

Table VI. Visual Observations and XRD Results of Phase 2 Glasses

BS-3

Observation

Homogeneity

Color

Comments

XRD

Observation

Homogeneity

Color

Comments

XRD

BS-3

Observation

Homogeneity

Color

Comments

XRD
BS-3

Excellent

Dk brown

Amorphous

Good

Dk brown

Gold streaks

Brown layer

at crucible

Amorphous

$\mathrm{Pb}$ Only Series

Pb Comm.

PFP-1 (750 C)

Good

Clear

Not glass

Lots of bubbles

Pinkish

Amorphous

Foamy

$\mathrm{Fe}\left(\mathrm{PO}_{3}\right)_{3}$

$80 \mathrm{~Pb} / 10 \mathrm{Cd} / 10 \mathrm{Cr}$ Series

Pb Comm.

PFP-1 (750 C)

$\mathrm{n} / \mathrm{a}$

$\mathrm{n} / \mathrm{a}$

$50 \mathrm{~Pb} / 50 \mathrm{Cu}$ Series

$\mathrm{Pb}$ Comm.

PFP-1 (750 C)

$\mathrm{n} / \mathrm{a}$

$\mathrm{n} / \mathrm{a}$
Black

Brown layer at crucible

Amorphous 
James C. Marra

October 19, 1995
WSRC-TR-95-0479, Rev. 0

Page 19 of 37

Table VII. TCLP Results for Phase 2 Glasses

BS-3

$\mathbf{P b}$ Only Series (releases in ppm)

RCRA Element $\mathrm{Pb}$ Comm.

PFP-1 (750 C) (TCLP Limit)

$\mathrm{Pb}$ (5 ppm)

2.868

1.700

2780

$80 \mathrm{~Pb} / 10 \mathrm{Cd} / 10 \mathrm{Cr}$ Series (releases in ppm)

BS-1 $\mathrm{Pb}$ Comm.

PFP-1 (750 C)

RCRA Element (TCLP Limit)

$\mathrm{Pb}$ (5 ppm) $\quad 3.137$

Cd $(1 \mathrm{ppm}) \quad 0.491$

Cr $(5 \mathrm{ppm}) \quad 0.101$

$\begin{array}{ll}\mathrm{n} / \mathrm{a} & \mathrm{n} / \mathrm{a} \\ \mathrm{n} / \mathrm{a} & \mathrm{n} / \mathrm{a} \\ \mathrm{n} / \mathrm{a} & \mathrm{n} / \mathrm{a}\end{array}$

$50 \mathrm{~Pb} / 50 \mathrm{Cu}$ Series (releases in ppm)

BS-1 Pb Comm. PFP-1 (750 C)

RCRA Element (TCLP Limit)
$\mathrm{Pb}$ (5 ppm)
2.404
$\mathrm{n} / \mathrm{a}$
$\mathrm{n} / \mathrm{a}$
$\mathrm{Cu}^{*} \quad 3.876$
$\mathrm{n} / \mathrm{a}$
$n / a$

* There is no TCLP Release Limit for Copper 
James C. Marra

October 19, 1995
WSRC-TR-95-0479, Rev. 0

Page 20 of 37

Table VII. Chemical Analysis of Select Glass Compositions

\begin{tabular}{|c|c|c|c|c|c|c|}
\hline \multirow[b]{4}{*}{ Component } & \multicolumn{6}{|c|}{ Component Concentration (wt \%) } \\
\hline & & & & & \multirow{2}{*}{\multicolumn{2}{|c|}{$\begin{array}{l}\text { Frit 165 TDS } \\
\text { Pb Only }\end{array}$}} \\
\hline & \multicolumn{2}{|c|}{ BS-2 Pb Only } & \multicolumn{2}{|c|}{ BS-3 Pb Only } & & \\
\hline & Target & Analyzed & Target & Analyzed & Target & Analyzed \\
\hline $\mathrm{SiO}_{2}$ & 40.58 & 39.54 & 40.58 & 39.37 & 40.58 & 40.30 \\
\hline $\mathrm{PbO}$ & 25.00 & 24.45 & 25.00 & 23.83 & 25.00 & 23.31 \\
\hline $\mathrm{Na}_{2} \mathrm{O}$ & 14.62 & 13.00 & 12.38 & 8.91 & 7.72 & 7.59 \\
\hline $\mathrm{Fe}_{2} \mathrm{O}_{3}$ & 9.22 & 9.84 & 9.22 & 9.41 & 9.22 & 9.14 \\
\hline $\mathrm{B}_{2} \mathrm{O}_{3}$ & 7.50 & 7.16 & 7.50 & 7.29 & 5.10 & 4.95 \\
\hline $\mathrm{Al}_{2} \mathrm{O}_{3}$ & 3.08 & 3.77 & 3.82 & 5.12 & 3.08 & 4.42 \\
\hline $\mathrm{Li}_{2} \mathrm{O}$ & - & - & 1.50 & 1.42 & 3.53 & 3.46 \\
\hline $\mathrm{MnO}_{2}$ & - & - & - & - & 2.18 & 1.70 \\
\hline $\mathrm{CaO}$ & - & - & - & - & 1.12 & 1.10 \\
\hline $\mathrm{ZrO}_{2}$ & - & - & - & - & 0.90 & 0.94 \\
\hline \multirow[t]{2}{*}{$\mathrm{MgO}$} & - & - & - & - & 0.60 & 0.55 \\
\hline & \multicolumn{2}{|c|}{ BS-1 $50 \mathrm{~Pb} / 50 \mathrm{Cu}$} & \multicolumn{2}{|c|}{$\begin{array}{c}\mathrm{BS}-3 \\
\mathrm{~Pb} / 10 \mathrm{Cd} / 10 \mathrm{Cr}\end{array}$} & \multicolumn{2}{|c|}{$\begin{array}{c}\text { Frit } 165 \text { TDS } \\
80 \mathrm{~Pb} / 10 \mathrm{Cd} / 10 \mathrm{Cr}\end{array}$} \\
\hline Component & Target & Analyzed & Target & Analyzed & Target & Analyzed \\
\hline$\overline{\mathrm{SiO}_{2}}$ & 40.58 & 39.21 & 40.58 & 39.42 & 40.58 & 40.39 \\
\hline $\mathrm{PbO}$ & 12.50 & 11.75 & 20.00 & 18.98 & 20.00 & 18.80 \\
\hline $\mathrm{Na}_{2} \mathrm{O}$ & 11.25 & 10.80 & 12.38 & 12.06 & 7.72 & 7.58 \\
\hline $\mathrm{Fe}_{2} \mathrm{O}_{3}$ & 9.22 & 9.58 & 9.22 & 9.65 & 9.22 & 9.09 \\
\hline $\mathrm{B}_{2} \mathrm{O}_{3}$ & 7.50 & 7.23 & 7.50 & 7.27 & 5.10 & 4.92 \\
\hline $\mathrm{Al}_{2} \mathrm{O}_{3}$ & 3.08 & 4.48 & 3.82 & 4.52 & 3.08 & 4.19 \\
\hline $\mathrm{Li}_{2} \mathrm{O}$ & 3.38 & 3.28 & 1.50 & 1.45 & 3.53 & 3.41 \\
\hline $\mathrm{MnO}_{2}$ & - & - & 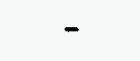 & - & 2.18 & 1.56 \\
\hline $\mathrm{CaO}$ & - & - & - & - & 1.12 & 1.09 \\
\hline $\mathrm{ZrO}_{2}$ & - & - & - & - & 0.90 & 0.96 \\
\hline $\mathrm{MgO}$ & - & - & - & - & 0.60 & 0.53 \\
\hline $\mathrm{CuO}$ & 12.50 & 11.82 & - & - & - & - \\
\hline $\mathrm{CdO}$ & - & - & 2.50 & 2.52 & 2.50 & 2.43 \\
\hline $\mathrm{Cr}_{2} \mathrm{O}_{3}$ & - & - & 2.50 & 1.792 .50 & & 2.08 \\
\hline
\end{tabular}


James C. Marra

October 19, 1995
WSRC-TR-95-0479, Rev. 0

Page 21 of 37
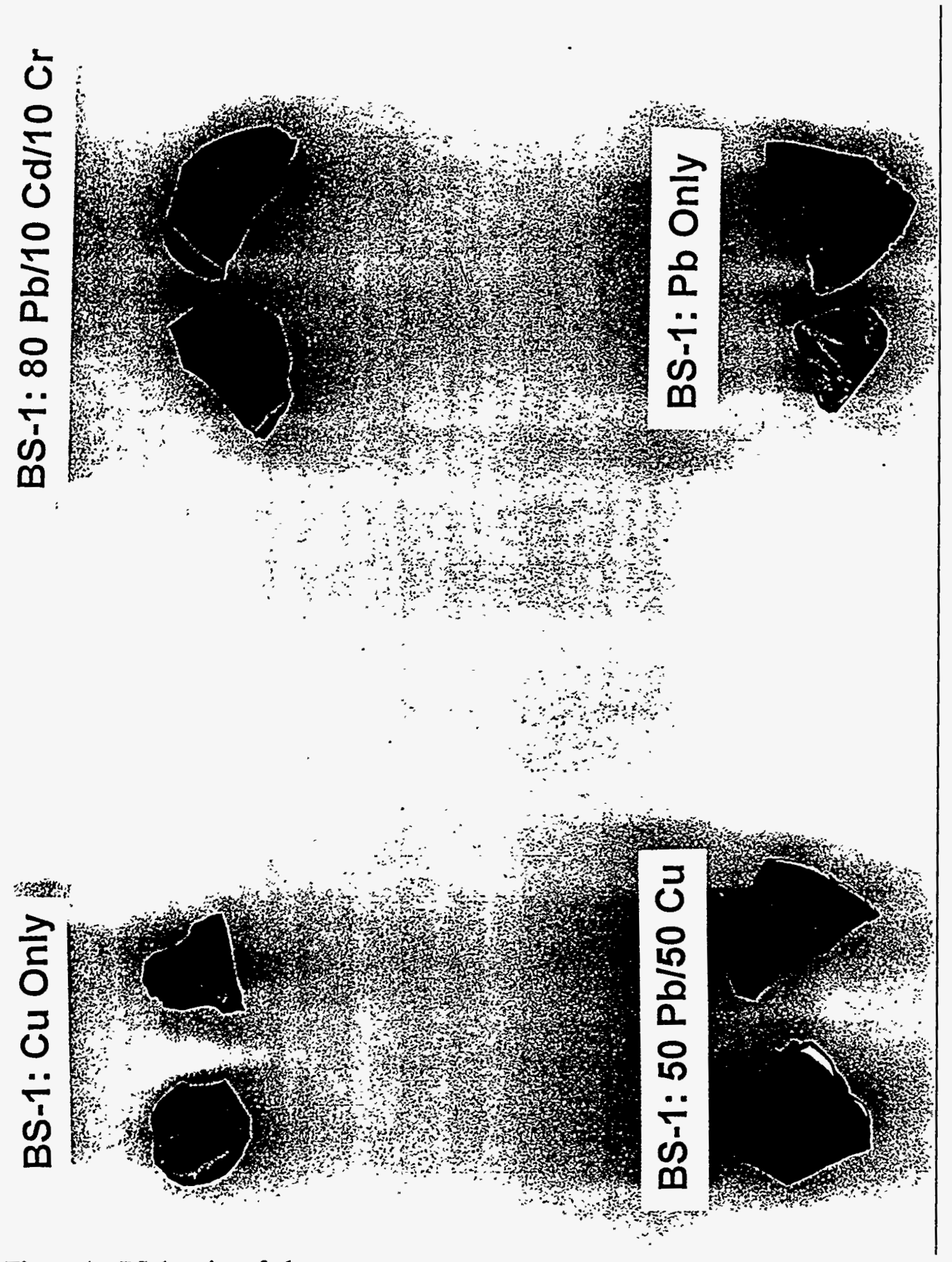

Figure 1. BS-1 series of glasses. 


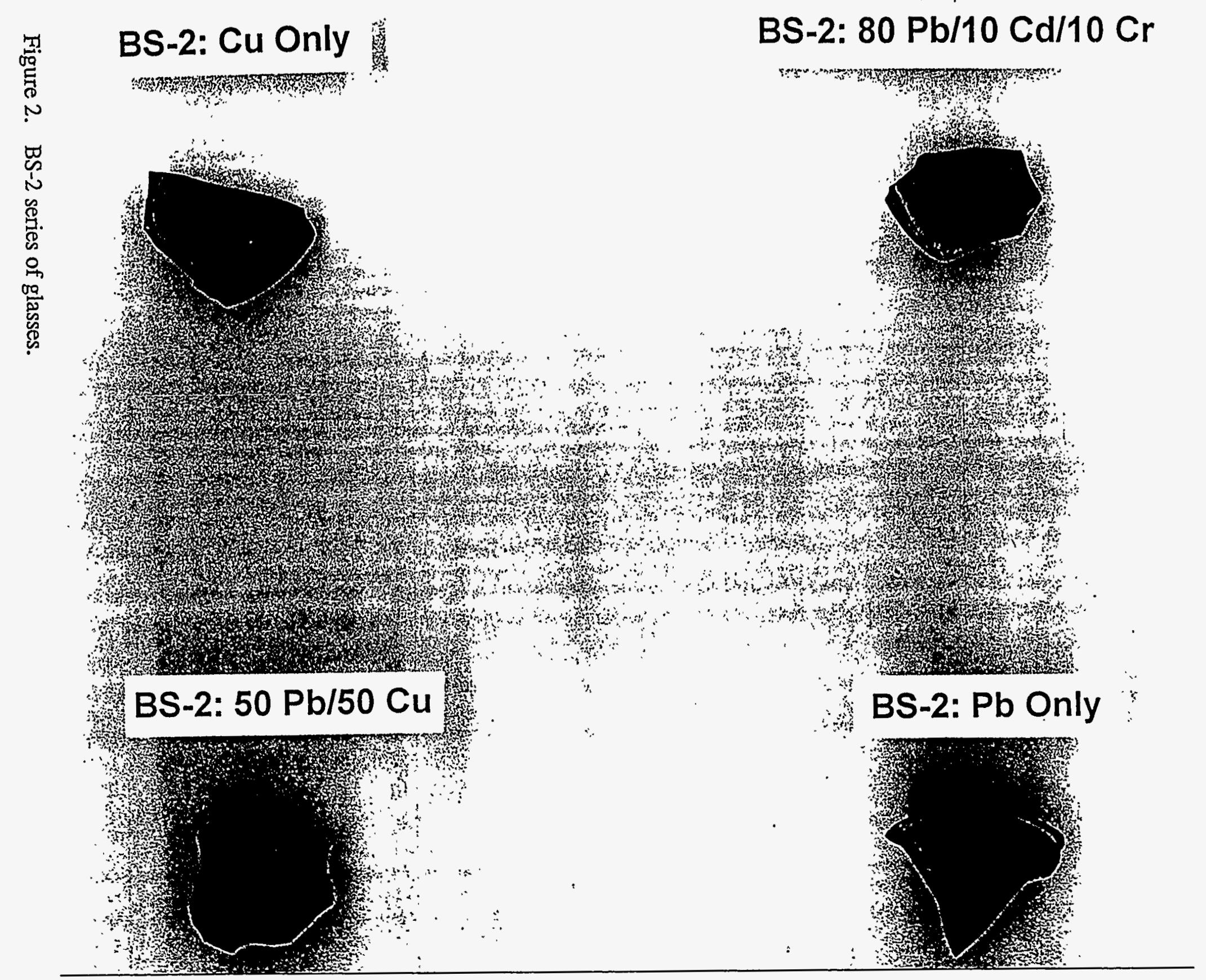


James C. Marra

October 19, 1995
WSRC-TR-95-0479, Rev. 0 Page 23 of 37
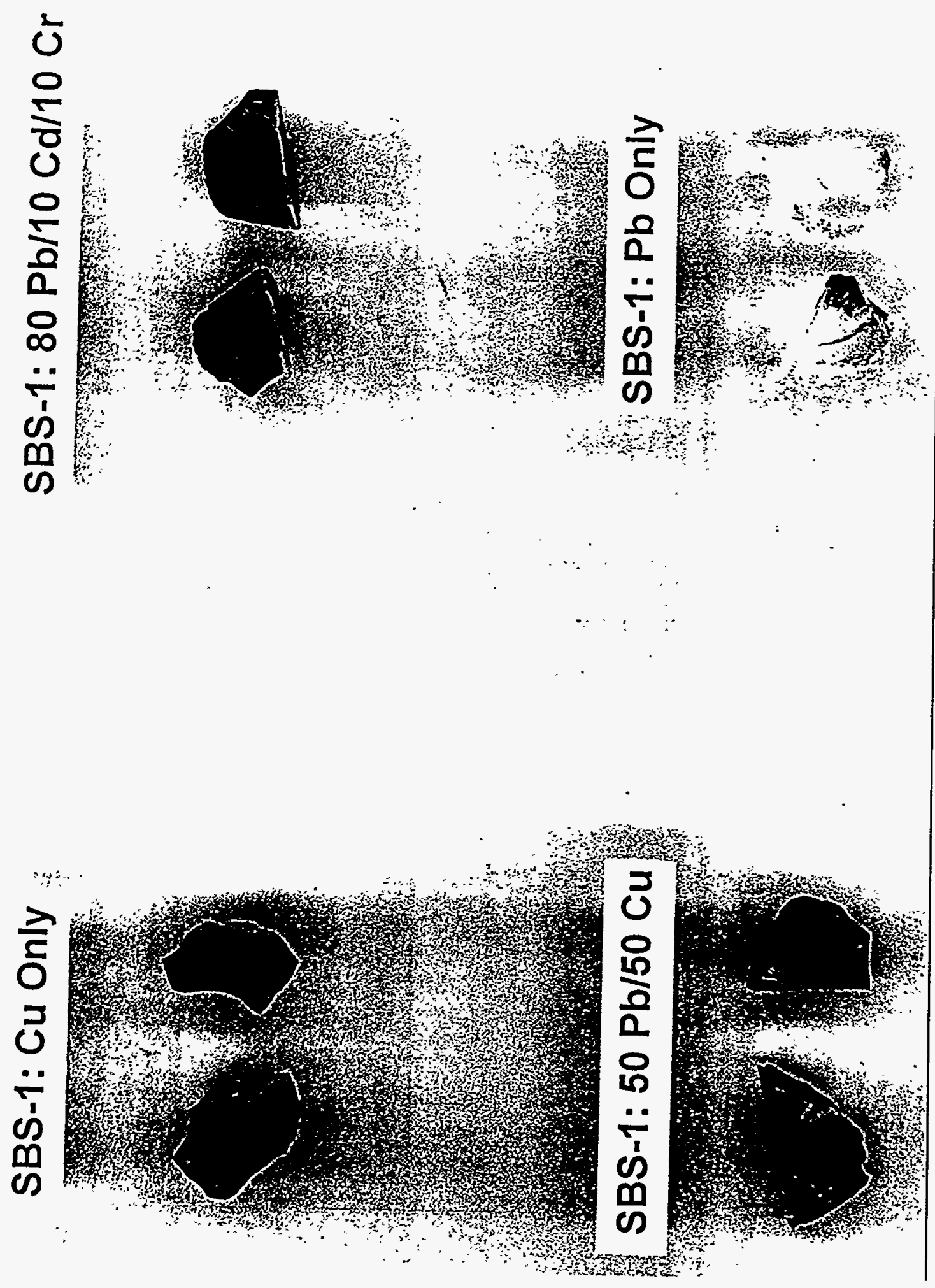

Figure 3. SBS-1 series of glasses. 


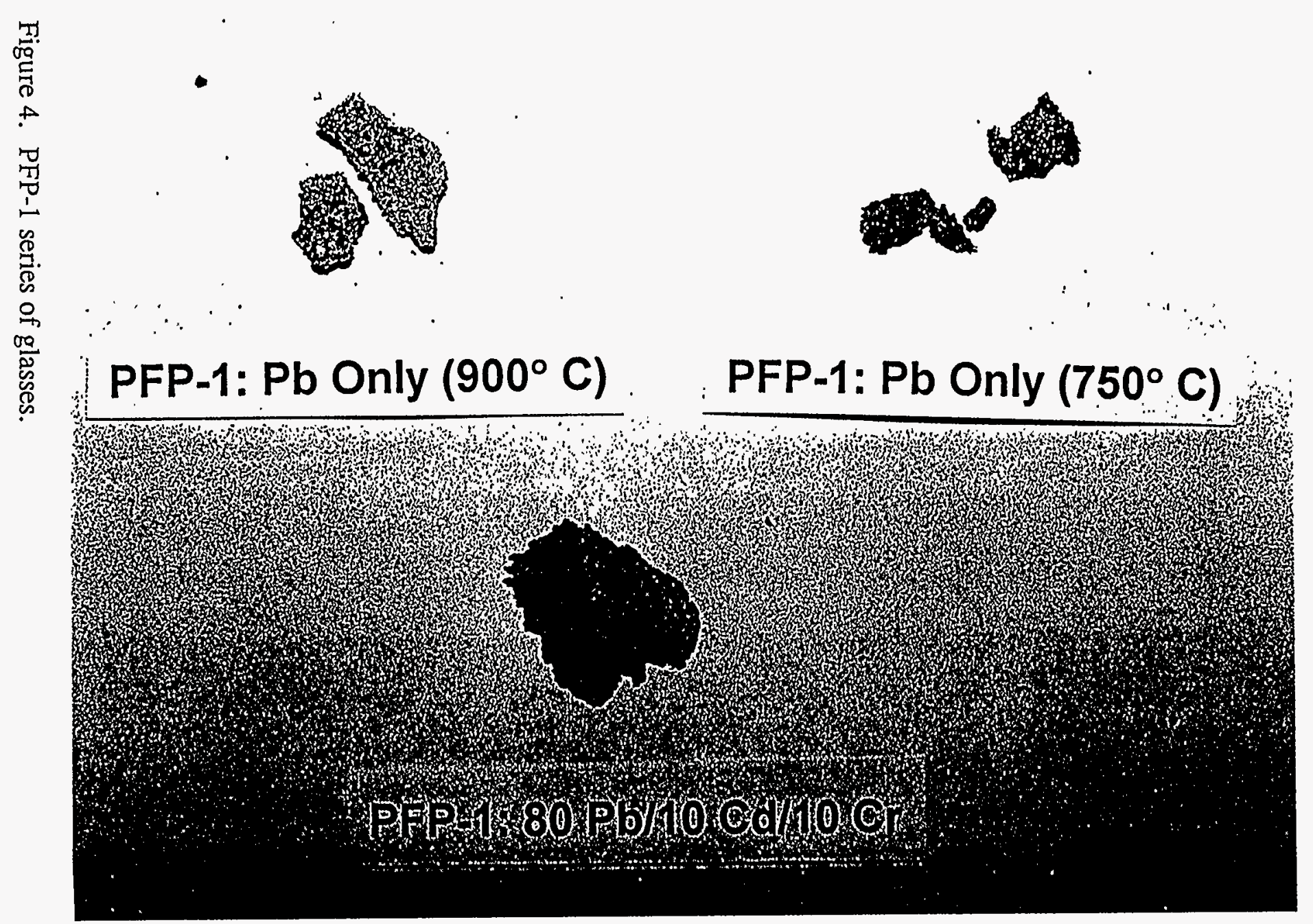


James C. Marra October 19, 1995
WSRC-TR-95-0479, Rev. 0 Page 25 of 37

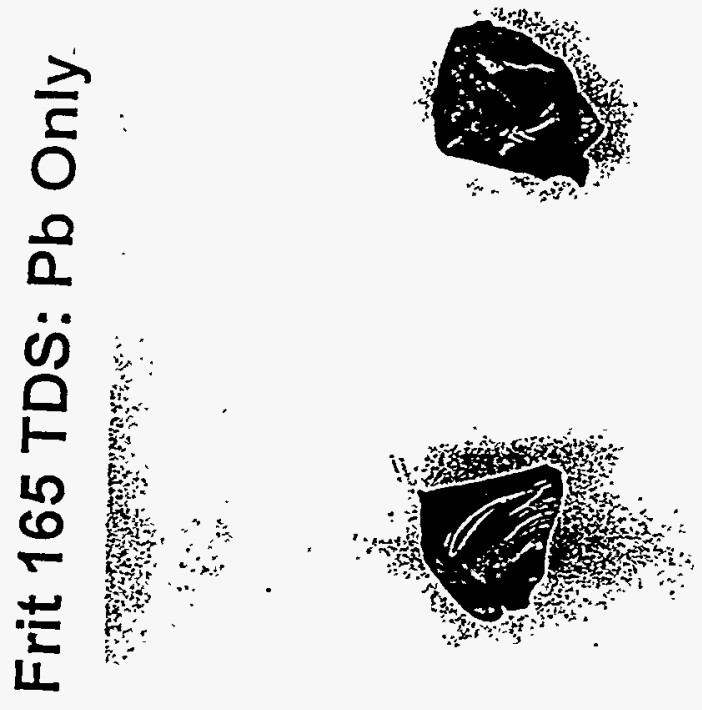

然

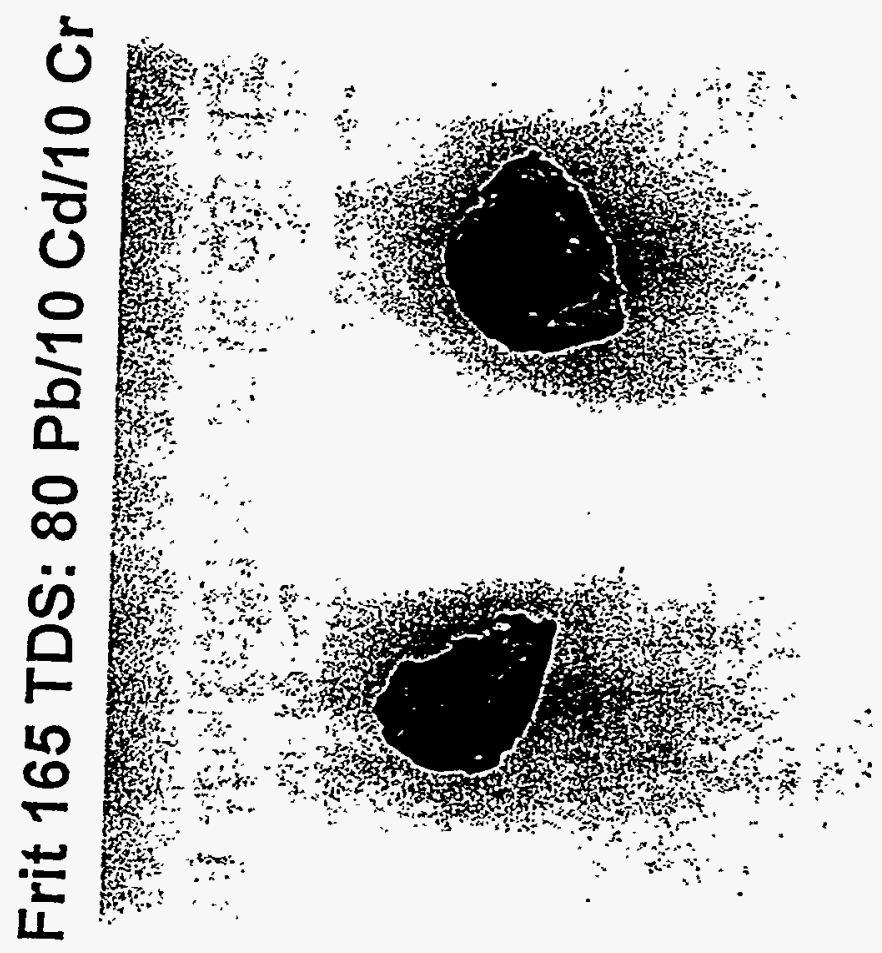

Figure 5. Frit 165 TDS series of glasses. 
James C. Marra

October 19, 1995
WSRC-TR-95-0479, Rev. 0

Page 26 of 37

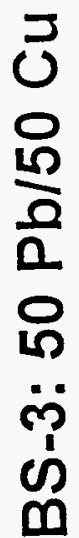

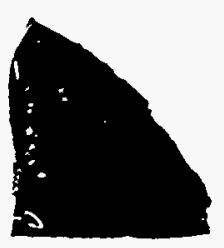

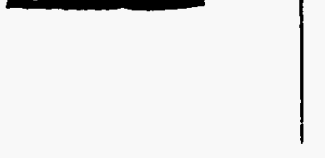

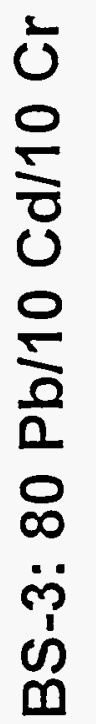
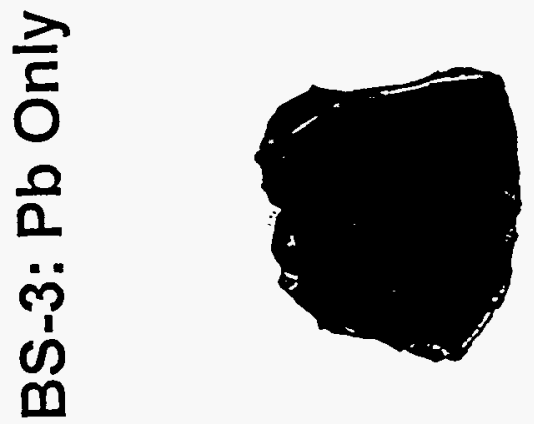

Figure 6. BS-3 series of glasses. 
James C. Marra

October 19, 1995
WSRC-TR-95-0479, Rev. 0

Page 27 of 37

\section{$\mathrm{Pb}$ Commercial: $\mathrm{Pb}$ Only}

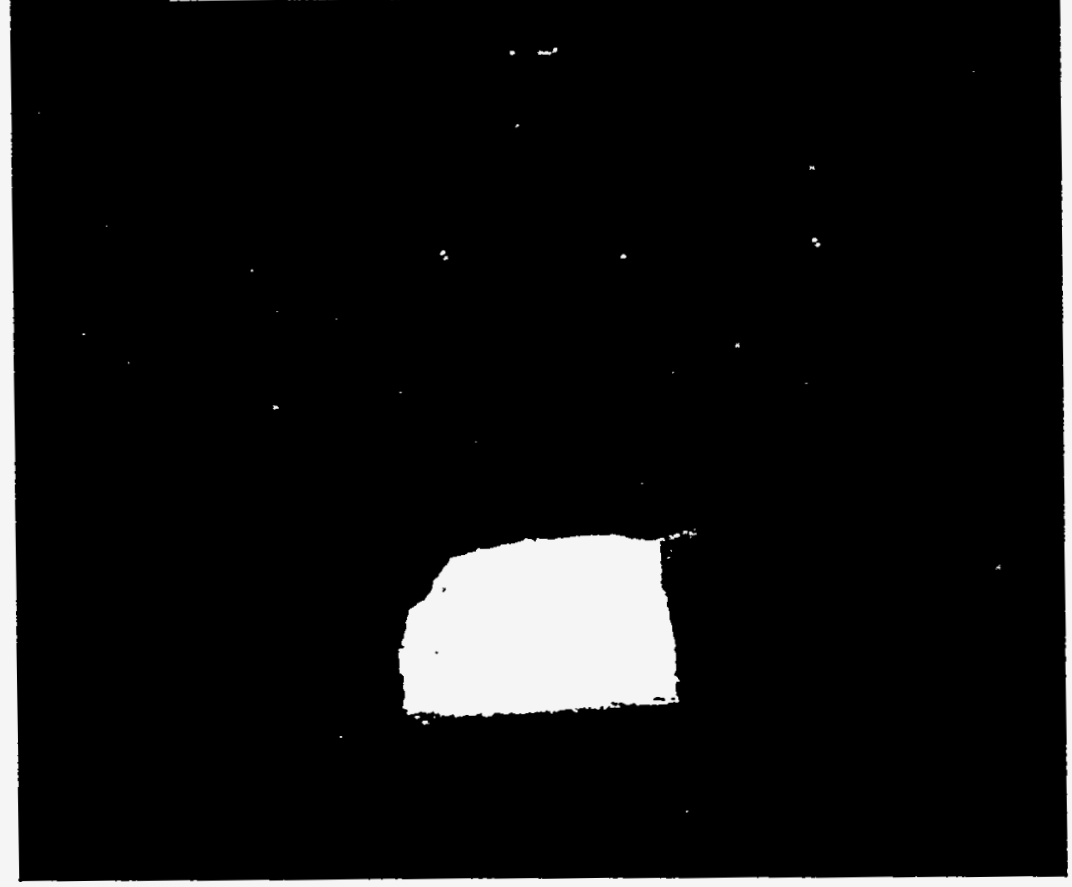

Figure 7. Commercial lead silicate composition. 
James C. Marra

October 19, 1995
WSRC-TR-95-0479, Rev. 0

Page 28 of 37

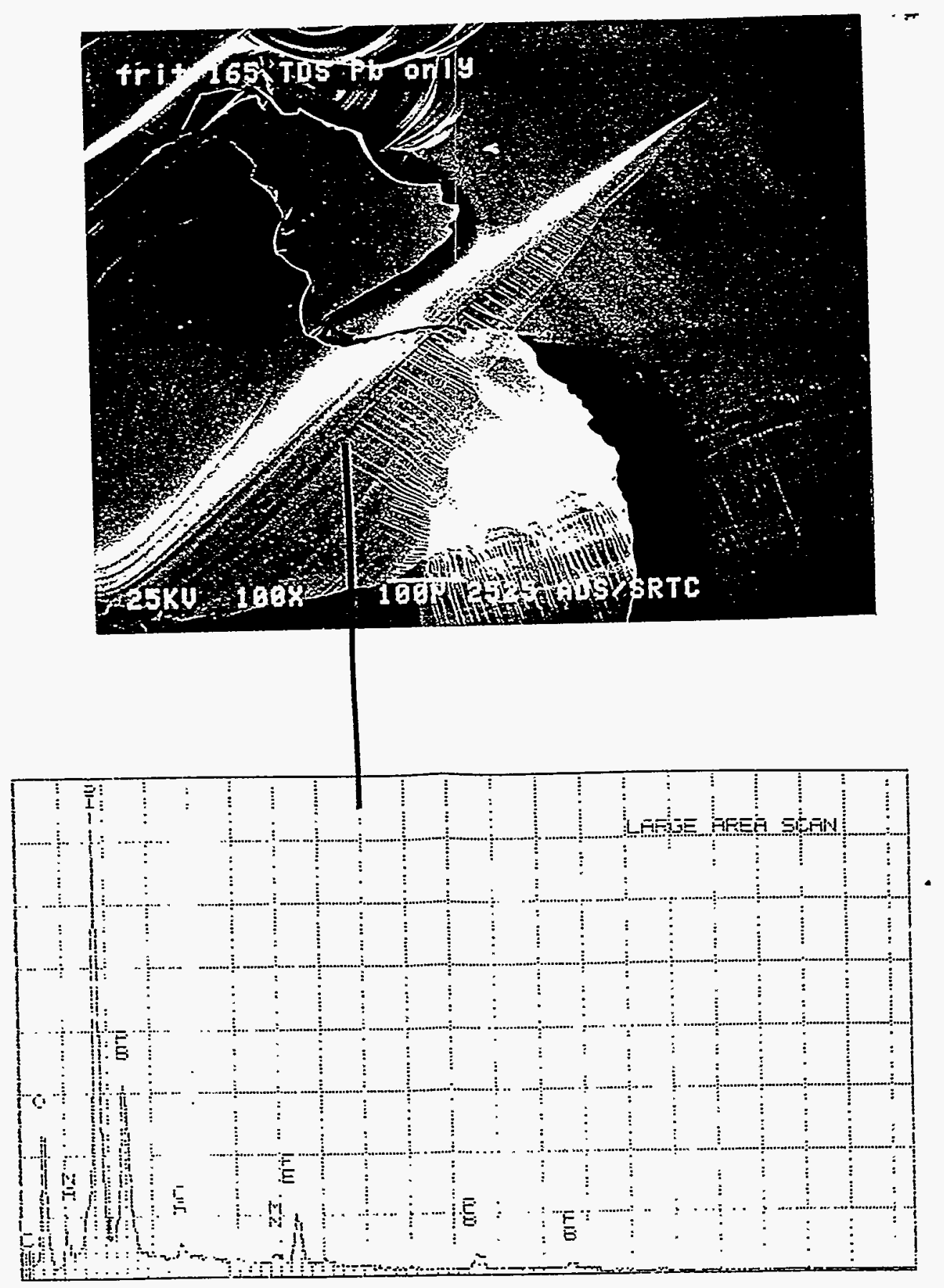

Figure 8. SEM micrograph and EDS spectra of Frit 165 TDS: Pb only glass. 
James C. Marra

October 19, 1995
WSRC-TR-95-0479, Rev. 0

Page 29 of 37
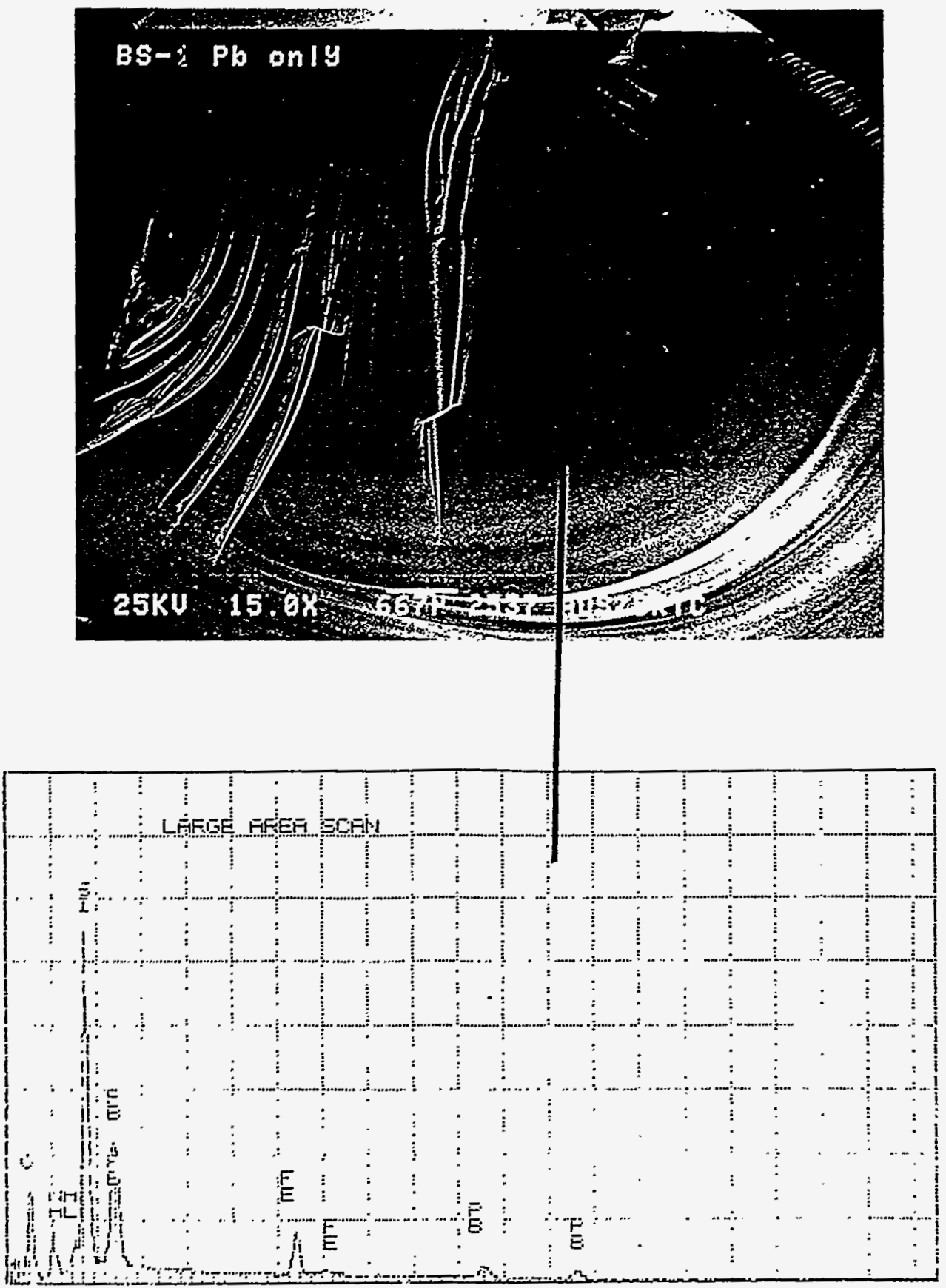

Figure 9. SEM micrograph and EDS spectra of BS-2: Pb only glass. 
James C. Marra

October 19, 1995
WSRC-TR-95-0479, Rev. 0

Page 30 of 37

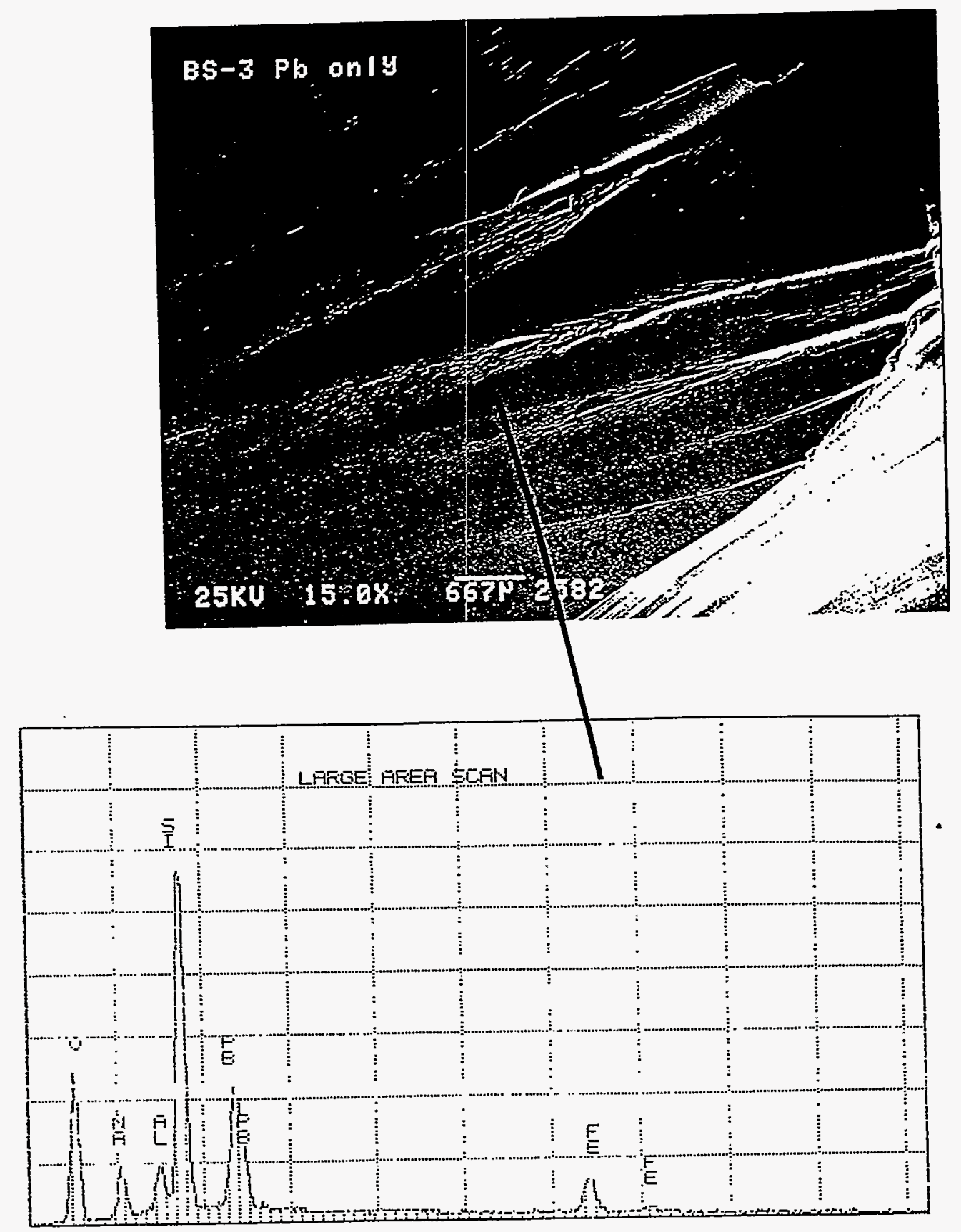

Figure 10. SEM micrograph and EDS spectra of $\mathrm{BS}-3$ : Pb only glass. 
James C. Marra

October 19, 1995

WSRC-TR-95-0479, Rev. 0

Page 31 of 37

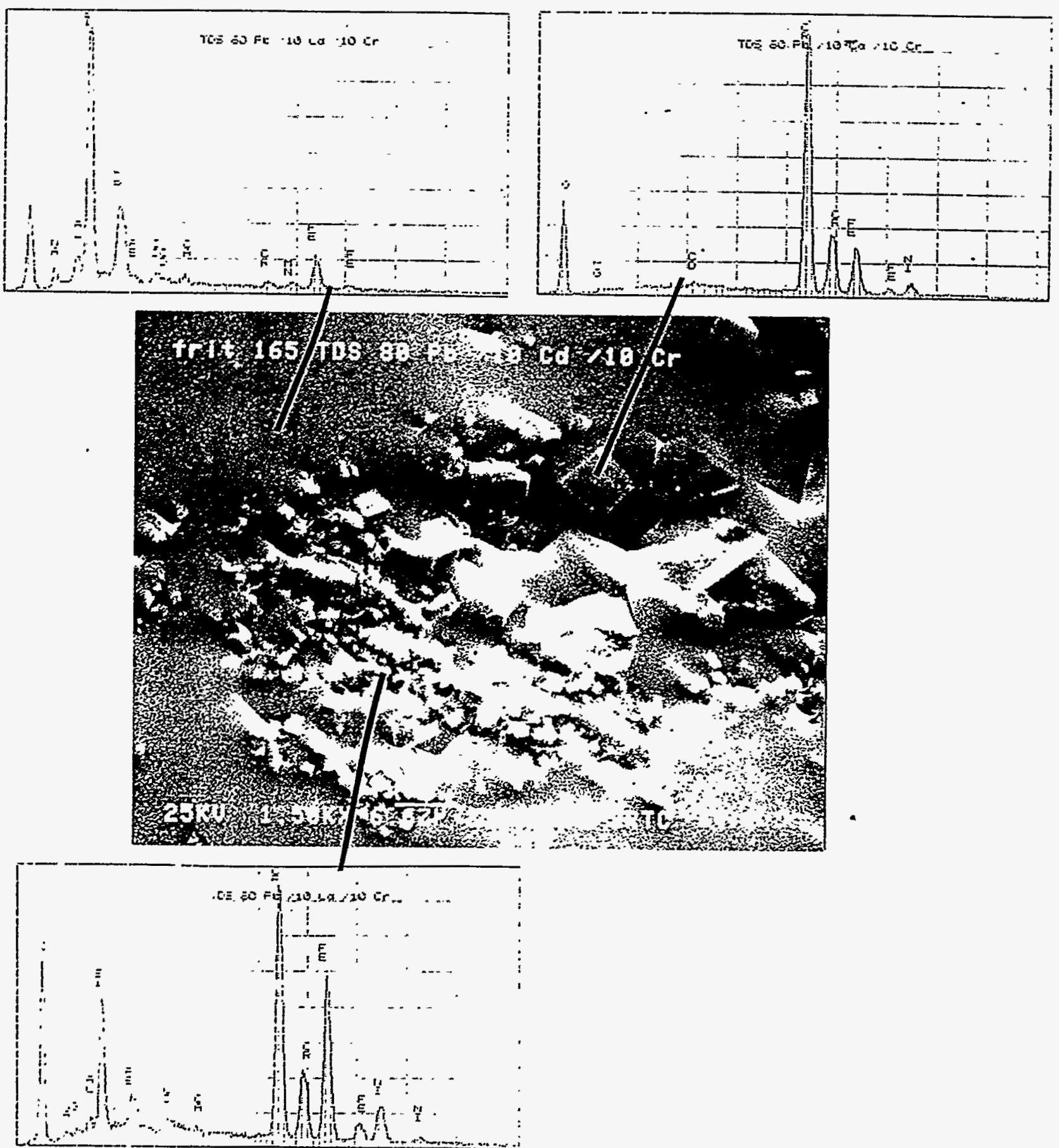

Figure 11. SEM micrograph and EDS spectra of Frit 165 TDS: $80 \mathrm{~Pb} / 10 \mathrm{Cd} / 10 \mathrm{Cr}$ glass. 
James C. Marra

October 19, 1995
WSRC-TR-95-0479, Rev. 0

Page 32 of 37

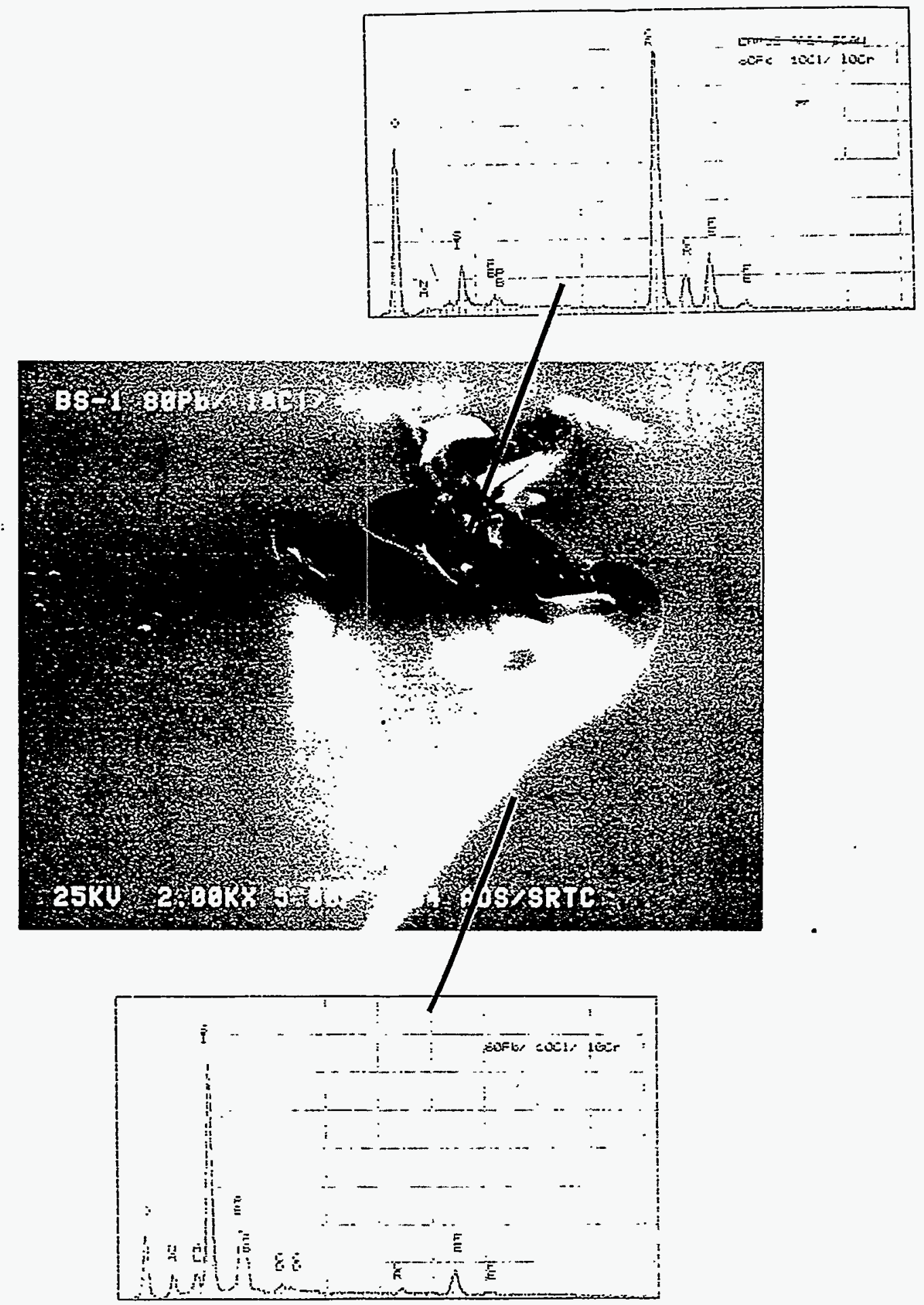

Figure 12. SEM micrograph and EDS spectra of $\mathrm{BS}-1: 80 \mathrm{~Pb} / 10 \mathrm{Cd} / 10 \mathrm{Cr}$ glass. 
James C. Marra

October 19, 1995
WSRC-TR-95-0479, Rev. 0

Page 33 of 37

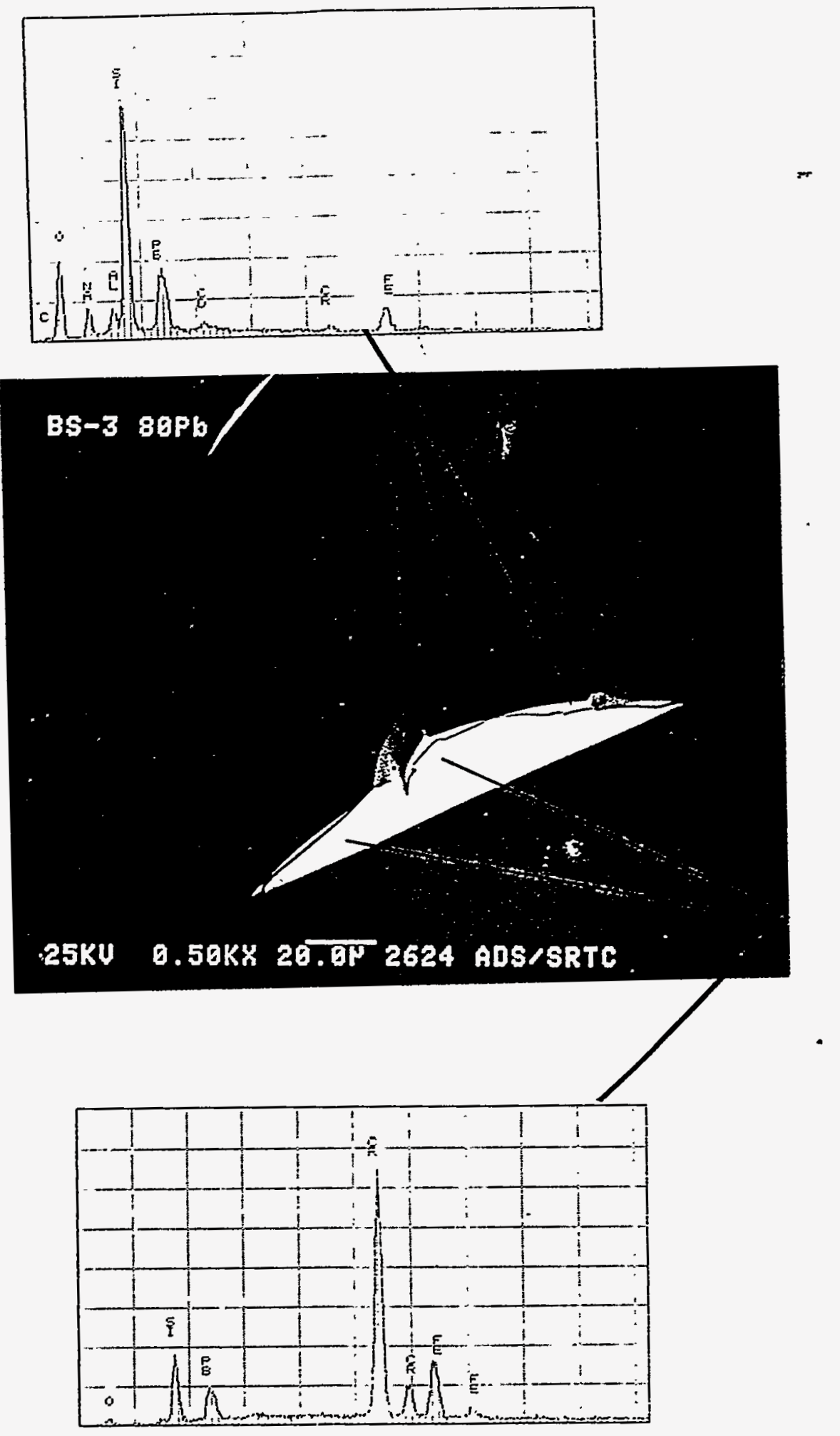

Figure 13. SEM micrograph and EDS spectra of BS-3: $80 \mathrm{~Pb} / 10 \mathrm{Cd} / 10 \mathrm{Cr}$ glass. 
James C. Marra

October 19, 1995
WSRC-TR-95-0479, Rev. 0

Page 34 of 37

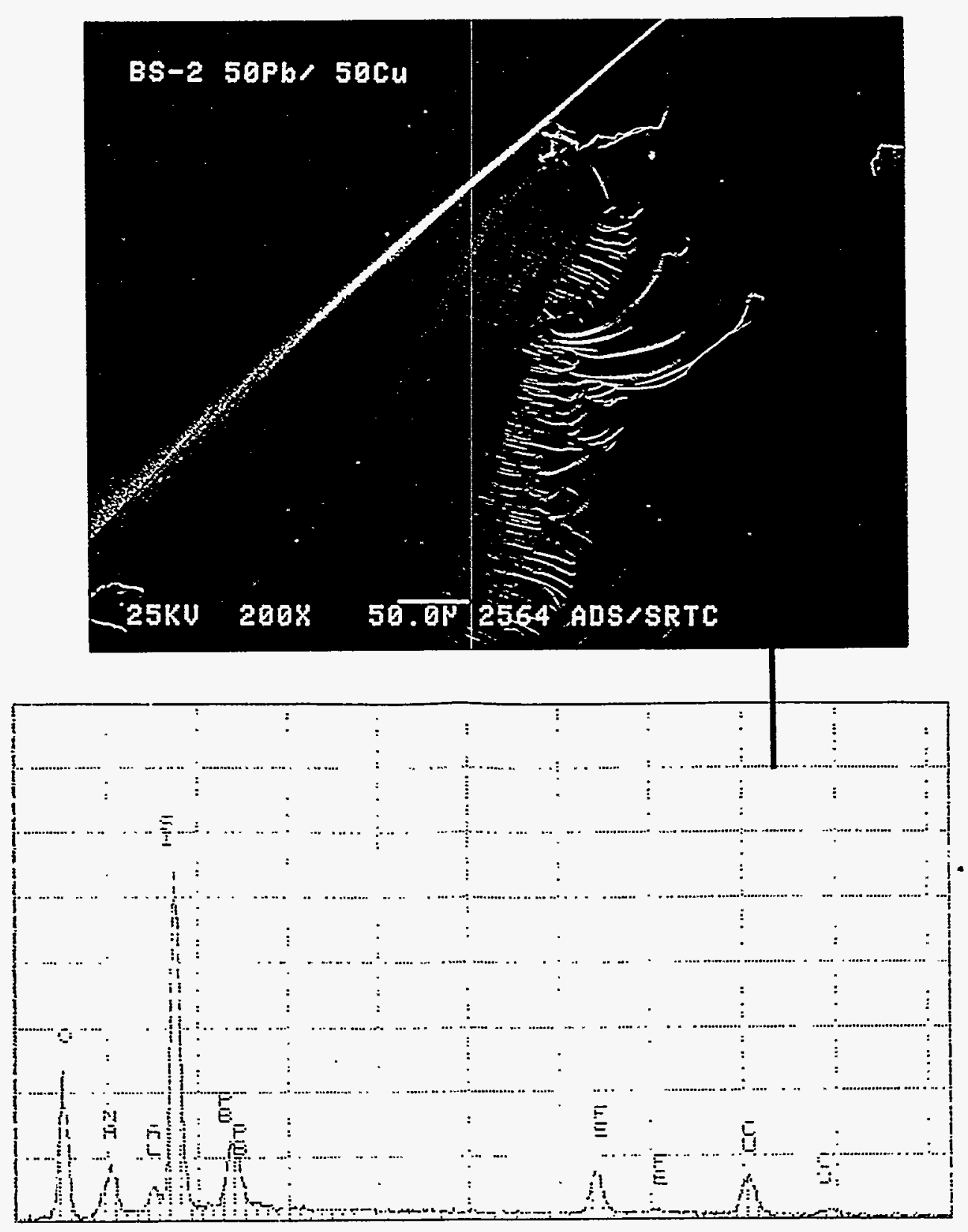

Figure 14. SEM micrograph and EDS spectra of BS-2: $50 \mathrm{~Pb} / 50 \mathrm{Cu}$ glass. 
James C. Marra

October 19, 1995
WSRC-TR-95-0479, Rev. 0 Page 35 of 37

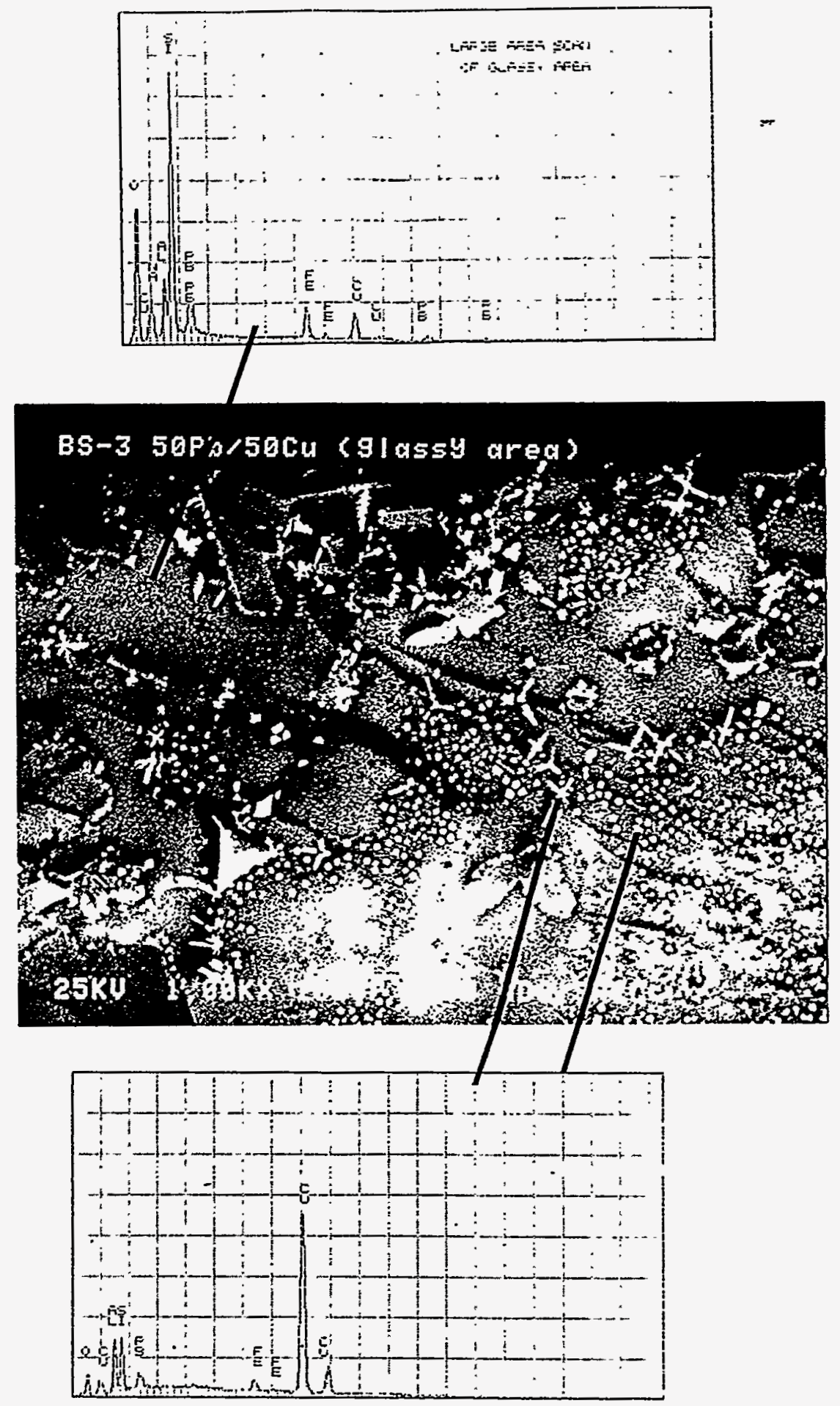

Figure 15. SEM micrograph and EDS spectra of BS-3: $50 \mathrm{~Pb} / 50 \mathrm{Cu}$ glass. 
James C. Marra

October 19, 1995
WSRC-TR-95-0479, Rev. 0

Page 36 of 37

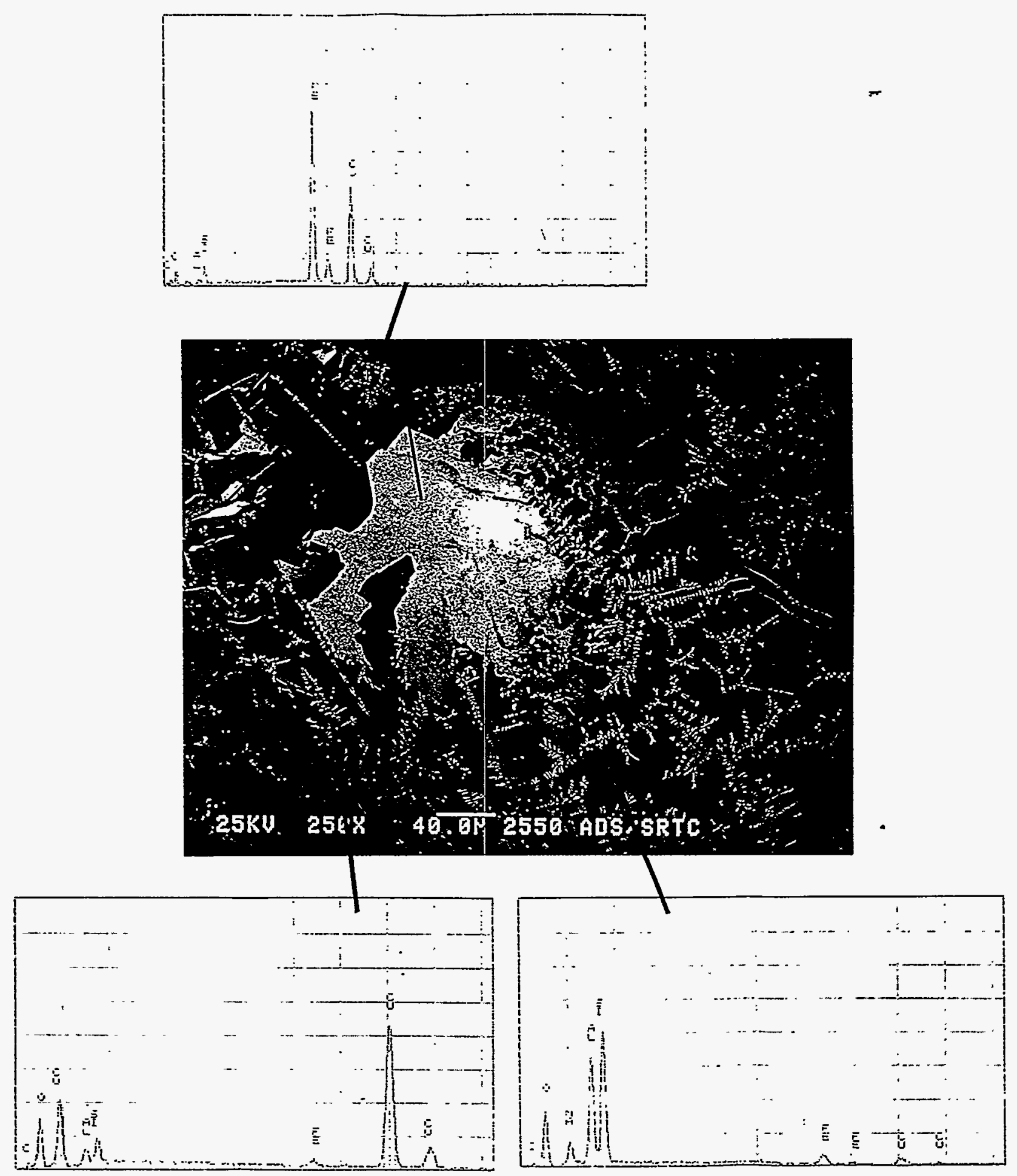

Figure 16. SEM micrograph and EDS spectra of BS-1: Cu only glass. 
James C. Marra

October 19, 1995
WSRC-TR-95-0479, Rev. 0

Page 37 of 37

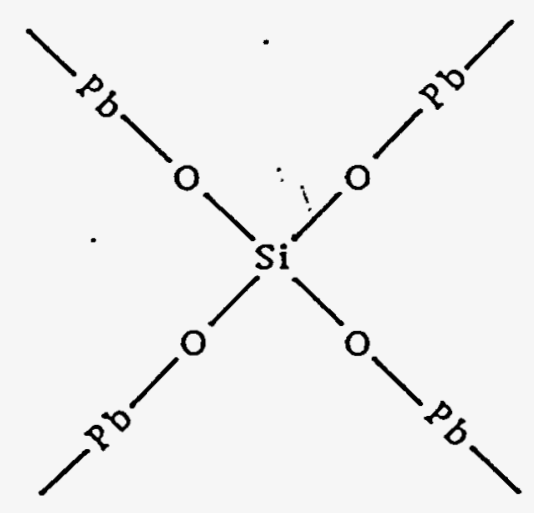

(a)

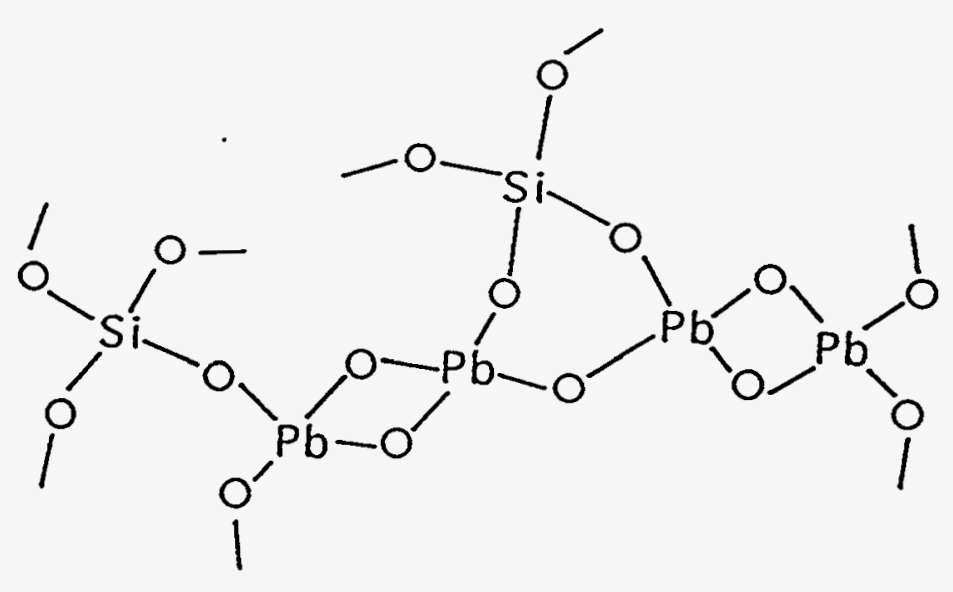

(b)

Figure 17. Structure of lead silicate glasses showing (a) two-coordinated $\mathrm{Pb}$, (b) tetrahedrally coordinated $\mathrm{Pb}[13]$. 

Glass Composition Development for Stabilization of Lead Based Paints - (U)

James C. Marra

Westinghouse Savannah River Company

Distribution:

L. M. Papouchado, 773-A

E. W. Holtzscheiter, 773-A

E. F. Duhn, 773-A

M. J. Plodinec, 773-43A

D. A. Crowley, 773-23A

J. R. Harbour, 773-43A

L. F. Landon, 704-1T

C. T. Randall, 704-T

N. E. Bibler, 773-A

D. F. Bickford, 773-43A

G. S. Bumgarner, 773-41A

C. A. Cicero, 773-41A

B. D. Helton, 773-41A

D. $T$. Herman, 773-41A

C. M. Jantzen, 773-A

A. L. Kielpinski, 773-41A

R. F. Schumacher, 773-41A

J. C. Whitehouse, 773-23A

W. G. Ramsey, 704-1T

M. K. Andrews, 773-A

J. M. Pareizs, 773-A

D. C. Beam, 773-A

D. M. Ferrara, 773-A

D. K. Peeler, 773-A

K. E. Mottel, 773-43A

STI, 703-43A (4) 
